Review

\title{
Surgical Management of the Axilla in Clinically Node-Positive Breast Cancer Patients Converting to Clinical Node Negativity through Neoadjuvant Chemotherapy: Current Status, Knowledge Gaps, and Rationale for the EUBREAST-03 AXSANA Study
}

\author{
Maggie Banys-Paluchowski ${ }^{1,2, *,+}$, Maria Luisa Gasparri ${ }^{3,4,+}{ }^{,}$Jana de Boniface ${ }^{5,6} \oplus^{\infty}$, Oreste Gentilini ${ }^{7}{ }^{\oplus}$, \\ Elmar Stickeler ${ }^{8}$, Steffi Hartmann ${ }^{9}{ }^{\circledR}$, Marc Thill ${ }^{10}$, Isabel T. Rubio ${ }^{11}$, Rosa Di Micco ${ }^{7}$, \\ Eduard-Alexandru Bonci ${ }^{12,13}{ }^{(0)}$, Laura Niinikoski ${ }^{14}{ }^{(}$, Michalis Kontos $\left.{ }^{15}{ }^{(}\right)$, Guldeniz Karadeniz Cakmak ${ }^{16}$, \\ Michael Hauptmann ${ }^{17}$, Florentia Peintinger ${ }^{18}$, David Pinto $\left.{ }^{19}{ }^{(}\right)$, Zoltan Matrai ${ }^{20}{ }^{\circ}$, Dawid Murawa ${ }^{21}{ }^{\circledR}$, \\ Geeta Kadayaprath ${ }^{22}$, Lukas Dostalek ${ }^{23}{ }^{-1}$, Helidon Nina ${ }^{24}$, Petr Krivorotko ${ }^{25}$, Jean-Marc Classe ${ }^{26}$ (1), \\ Ellen Schlichting ${ }^{27}$, Matilda Appelgren ${ }^{5}$, Peter Paluchowski ${ }^{28}$, Christine Solbach ${ }^{29}{ }^{\circledR}$, Jens-Uwe Blohmer ${ }^{30}$, \\ Thorsten Kühn ${ }^{31}$ and the AXSANA Study Group ${ }^{\ddagger}$
}

check for

updates

Citation: Banys-Paluchowski, M.; Gasparri, M.L.; de Boniface, J.; Gentilini, O.; Stickeler, E.; Hartmann, S.; Thill, M.; Rubio, I.T.; Di Micco, R.; Bonci, E.-A.; et al. Surgical Management of the Axilla in Clinically Node-Positive Breast Cancer Patients Converting to Clinical Node Negativity through Neoadjuvant Chemotherapy: Current Status, Knowledge Gaps, and Rationale for the EUBREAST-03 AXSANA Study. Cancers 2021, 13 , 1565. https://doi.org/10.3390/ cancers 13071565

Academic Editor: Gilles Freyer

Received: 3 March 2021

Accepted: 22 March 2021

Published: 29 March 2021

Publisher's Note: MDPI stays neutral with regard to jurisdictional claims in published maps and institutional affiliations.

Copyright: (c) 2021 by the authors. Licensee MDPI, Basel, Switzerland. This article is an open access article distributed under the terms and conditions of the Creative Commons Attribution (CC BY) license (https:/ / creativecommons.org/licenses/by/ $4.0 /)$.
1 Department of Obstetrics and Gynecology, Campus Lübeck, University Hospital of Schleswig Holstein, 23538 Lübeck, Germany

2 Medical Faculty, Heinrich-Heine-University Düsseldorf, 40225 Düsseldorf, Germany

3 Department of Gynecology and Obstetrics, Ente Ospedaliero Cantonale, Ospedale Regionale di Lugano, 6900 Lugano, Switzerland; MariaLuisa.Gasparri@eoc.ch

4 Faculty of Biomedicine, University of the Italian Switzerland (USI), 6900 Lugano, Switzerland

5 Department of Molecular Medicine and Surgery, Karolinska Institutet, 17177 Stockholm, Sweden; jana.de-boniface@ki.se (J.d.B.); matilda.appelgren@ki.se (M.A.)

6 Department of Surgery, Capio St. Göran's Hospital, 11219 Stockholm, Sweden

7 Breast Surgery Unit, San Raffaele Hospital Milan, 20132 Milano MI, Italy; gentilini.oreste@hsr.it (O.G.); dimicco.rosa@hsr.it (R.D.M.)

8 Department of Gynecology and Obstetrics, University Hospital Aachen, 52074 Aachen, Germany; estickeler@ukaachen.de

9 Department of Gynecology and Obstetrics, University Hospital Rostock, 18059 Rostock, Germany; steffi.hartmann@kliniksued-rostock.de

10 Department of Gynecology and Gynecological Oncology, AGAPLESION Markus Krankenhaus, 60431 Frankfurt am Main, Germany; marc.thill@fdk.info

11 Breast Surgical Unit, Clínica Universidad de Navarra, 28027 Madrid, Spain; irubior@unav.es

12 Department of Surgical Oncology, "Prof. Dr. Ion Chiricuță” Institute of Oncology, 400015 Cluj-Napoca, Romania; bonci.eduard@gmail.com

13 11th Department of Oncological Surgery and Gynecological Oncology, "Iuliu Hațieganu” University of Medicine and Pharmacy, 400012 Cluj-Napoca, Romania

14 Breast Surgery Unit, Comprehensive Cancer Center, Helsinki University Hospital, University of Helsinki, 00280 Helsinki, Finland; laura.niinikoski@hus.fi

15 1st Department of Surgery, Laiko Hospital, National and Kapodistrian University of Athens, 11527 Athens, Greece; michalis_kontos@yahoo.com

16 Breast and Endocrine Unit, General Surgery Department, Zonguldak BEUN The School of Medicine, Kozlu/Zonguldak 67600, Turkey; gkkaradeniz@yahoo.com

17 Brandenburg Medical School Theodor Fontane, 16816 Neuruppin, Germany; Michael.Hauptmann@mhb-fontane.de

18 Institut für Pathologie, Medical University of Graz, 8010 Graz, Austria; florentia.peintinger@medunigraz.at

19 Champalimaud Clinical Center, Breast Unit, Champalimaud Foundation, 1400-038 Lisboa, Portugal; davidgomespinto@gmail.com

20 Department of Breast and Sarcoma Surgery, National Institute of Oncology, 1122 Budapest, Hungary; matraidoc@gmail.com

21 Collegium Medicum, University of Zielona Góra, 65-046 Zielona Góra, Poland; dmurawa@gmail.com

22 Breast Surgical Oncology and Oncoplastic Surgery, Max Institute of Cancer Care, Max Healthcare Delhi, Delhi 110092, India; dr_kaygee@hotmail.com

23 Gynecologic Oncology Center, Department of Obstetrics and Gynecology, First Faculty of Medicine, Charles University, General University Hospital, 12800 Prague, Czech Republic; Lukas.Dostalek@vfn.cz

24 Oncology Hospital, University Hospital Center "Nene Tereza", 1000 Tirana, Albania; ninahelios@yahoo.com 
25 Petrov Research Institute of Oncology, 197758 Saint-Petersburg, Russia; dr.krivorotko@mail.ru

26 Department of surgical oncology, Institut de cancerologie de l'Ouest Nantes, 44800 Saint Herblain, France; jean-marc.classe@ico.unicancer.fr

27 Department for Breast and Endocrine Surgery, Oslo University Hospital, 0188 Oslo, Norway; elschl@ous-hf.no

28 Department of Gynecology and Obstetrics, Regio Klinikum Pinneberg, 25421 Pinneberg, Germany; peterpaluchowski@gmail.com

29 Breast Center, Department of Gynecology and Obstetrics, University of Frankfurt, 60590 Frankfurt am Main, Germany; Christine.Solbach@kgu.de

30 Department of Gynecology and Breast Cancer Center, Charite Berlin, 10117 Berlin, Germany; jens.blohmer@charite.de

31 Department of Gynecology and Obstetrics, Klinikum Esslingen, 73730 Esslingen, Germany; kuehn.thorsten@t-online.de

* Correspondence: m.banys@outlook.com

+ Maggie Banys-Paluchowski and Maria Luisa Gasparri contributed equally to this manuscript.

$\ddagger$ A complete list of Collaborators and Members of the AXSANA Study Group as well as active study sites is provided in Appendix A.

Simple Summary: Currently, it is unclear which kind of axillary staging surgery breast cancer patients with lymph node metastasis should receive after neoadjuvant chemotherapy. For decades, these patients have been treated with a full axillary lymph node dissection, even if they converted to clinical node negativity. However, the removal of a large number of lymph nodes during the procedure can increase arm morbidity and impact quality of life. Therefore, several studies investigated less radical surgical strategies in this setting, such as sentinel lymph node biopsy or targeted axillary dissection, i.e., removal of a previously marked node combined with sentinel node removal. In this review, we summarize current evidence on the different surgical techniques and compare national and international recommendations. We show that many questions regarding oncological safety of different surgery types and the optimal marking technique remain unanswered and present the multinational prospective cohort study AXSANA that will address these open issues.

Abstract: In the last two decades, surgical methods for axillary staging in breast cancer patients have become less extensive, and full axillary lymph node dissection (ALND) is confined to selected patients. In initially node-positive patients undergoing neoadjuvant chemotherapy, however, the optimal management remains unclear. Current guidelines vary widely, endorsing different strategies. We performed a literature review on axillary staging strategies and their place in international recommendations. This overview defines knowledge gaps associated with specific procedures, summarizes currently ongoing clinical trials that address these unsolved issues, and provides the rationale for further research. While some guidelines have already implemented surgical de-escalation, replacing ALND with, e.g., sentinel lymph node biopsy (SLNB) or targeted axillary dissection (TAD) in cN+ patients converting to clinical node negativity, others recommend ALND. Numerous techniques are in use for tagging lymph node metastasis, but many questions regarding the marking technique, i.e., the optimal time for marker placement and the number of marked nodes, remain unanswered. The optimal number of SLNs to be excised also remains a matter of debate. Data on oncological safety and quality of life following different staging procedures are lacking. These results provide the rationale for the multinational prospective cohort study AXSANA initiated by EUBREAST, which started enrollment in June 2020 and aims at recruiting 3000 patients in 20 countries (NCT04373655; Funded by AGO-B, Claudia von Schilling Foundation for Breast Cancer Research, AWOgyn, EndoMag, Mammotome, and MeritMedical).

Keywords: neoadjuvant therapy; breast cancer; therapy response; targeted axillary dissection; marked lymph node 


\section{Introduction}

In breast cancer patients, the optimal surgical management of the axilla has been controversially discussed over the last two decades. For many years, axillary lymph node dissection (ALND) has been considered as the standard of care. The rationale behind this was firstly to assess the pathological lymph node status (diagnostic value, "staging") and secondly to provide locoregional control (therapeutic value). Due to its high morbidity, this approach has gradually been abandoned in favor of sentinel lymph node biopsy (SLNB), a less invasive procedure for axillary staging of clinically node-negative patients, over the past two decades. In recent years, SLNB has also become standard of care for patients with clinically unsuspicious nodes at time of diagnosis who have completed neoadjuvant chemotherapy. The detection rate and accuracy of SLNB are excellent in this setting, and axillary recurrence rates are negligible [1-3].

Nonetheless, in patients with clinically apparent axillary lymph node metastases $(\mathrm{cN}+)$ at time of diagnosis who achieve complete clinical response in the axilla (ycNO) after neoadjuvant chemotherapy (NACT), it is unclear which axillary surgical staging strategy should be offered. This uncertainty is expressed in the heterogeneity of recommendations endorsed by different national and international societies, which range from SLNB to targeted axillary dissection (TAD) or ALND (Tables 1 and 2). Some societies do not consider SLNB standard of care in this setting because of the relatively high false negative rates (FNRs) reported in large prospective trials and confirmed in a meta-analysis [1,4-6]. In the SENTINA and the ACOSOG Z1071 trials, FNRs were $12 \%$ and $14 \%$ respectively, and thus higher than the arbitrarily chosen but widely accepted cut-off value of 10\% (Table 3). So far, however, only limited data regarding the oncologic outcome following SLNB alone are available in this setting [3].

Table 1. Axillary surgical staging techniques: The most important definitions.

\begin{tabular}{ll}
\hline \multicolumn{1}{c}{ Type of Surgery } & \multicolumn{1}{c}{ Description } \\
\hline Axillary lymph node dissection (ALND) & $\begin{array}{l}\text { Systematic removal of lymph nodes from the } \\
\text { axilla, usually level I and II, sometimes } \\
\text { including also level III }\end{array}$ \\
\hline Sentinel lymph node biopsy (SLNB) & $\begin{array}{l}\text { Identification and removal of the sentinel } \\
\text { lymph node, usually using radioactive tracer } \\
\text { (Technetium-99) or blue dye }\end{array}$ \\
\hline Targeted lymph node biopsy (TLNB) & $\begin{array}{l}\text { Selective removal of metastatic lymph node(s) } \\
\text { marked before neoadjuvant therapy }\end{array}$ \\
\hline Targeted axillary dissection (TAD) & Combination of TLNB and SLNB \\
\hline
\end{tabular}

Marking positive lymph nodes at the time of diagnosis and prior to neoadjuvant chemotherapy with clips, coils, radioactive seeds, or other markers may improve the FNR of de-escalated surgical staging procedures $[7,8]$. The best marking technique, however, has not been unanimously identified yet. Importantly, data comparing recurrence rates and surgical morbidity among SLNB, ALND, and TAD are so far not available.

As a result, the German S3 guidelines updated in 2020 recommend ALND after NACT in $\mathrm{cN}+$ patients, as do Austrian and Scandinavian guidelines. As a contrast, high-impact networks such as European Society of Medical Oncology (ESMO) in Europe and National Comprehensive Cancer Network (NCCN) in the USA recommend SLNB, provided that dual tracers are used and a minimum of three sentinel nodes are removed $[9,10]$. In countries such as Italy, Denmark, Russia, and Hungary, SLNB or TAD are accepted as first choice for axillary staging in this group of patients. The German Breast Committee of the Working Group for Gynaecological Oncology (AGO Breast Committee) endorses both TAD and ALND as recommended strategies [11].

Unanswered questions include the role of axillary imaging for selection of patients who might safely be offered surgical de-escalation [12]. Further, the necessity of regional 
therapy, e.g., radiotherapy following axillary staging in patients with pathological complete response on SLNB or TAD, is still a matter of debate.

Table 2. National and international guidelines on axillary surgical staging in initially node-positive patients receiving neoadjuvant therapy.

\begin{tabular}{|c|c|c|}
\hline National/International: & Staging Recommendation for $\mathrm{cN}+\rightarrow$ ycNo Patients & $\begin{array}{l}\text { Level of Evidence/Grade of } \\
\text { Recommendation }\end{array}$ \\
\hline $\begin{array}{l}\text { European Society for Medical Oncology } \\
\text { (ESMO) [10] }\end{array}$ & $\begin{array}{l}\text { Sentinel lymph node biopsy (SLNB) can be an option, as } \\
\text { long as additional recommendations are followed (e.g., } \\
\text { dual tracer, clipping/marking of positive nodes, } \\
\text { minimum of three sentinel nodes removed) }\end{array}$ & III, B \\
\hline $\begin{array}{l}\text { National Comprehensive Cancer Network } \\
\text { (NCCN) [9] }\end{array}$ & $\begin{array}{l}\text { Consider SLNB. Relatively high false-negative rate (FNR) } \\
\text { ( }>10 \% \text { ) can be improved by marking biopsied lymph } \\
\text { nodes to document their removal, using dual tracer, and } \\
\text { by removing more than } 2 \text { sentinel nodes }\end{array}$ & 2B \\
\hline American Society of Breast Surgeons [13] & $\begin{array}{l}\text { If SLNB after neoadjuvant therapy is attempted, dual } \\
\text { tracer should be used. If a SLN and/or the clipped node } \\
\text { (if clipped) is not identified, an Axillary lymph node } \\
\text { dissection (ALND) is recommended }\end{array}$ & Not provided \\
\hline Finland [14] & ALND & Not provided \\
\hline Germany (S3 guideline) [15] & ALND & $2 b, B$ \\
\hline Germany (AGO Breast Committee) [11] & $\begin{array}{l}\text { Targeted axillary dissection (TAD): + (i.e., this } \\
\text { investigation or therapeutic intervention is of limited } \\
\text { benefit for patients and can be performed) } \\
\text { ALND: + (i.e., this investigation or therapeutic } \\
\text { intervention is of limited benefit for patients and can be } \\
\text { performed) } \\
\text { SLNB only: +/ - (i.e., this investigation or therapeutic } \\
\text { intervention has not shown benefit for patients and may } \\
\text { be performed only in individual cases. According to } \\
\text { current knowledge a general recommendation cannot be } \\
\text { given) }\end{array}$ & $2 b, B$ \\
\hline Hungary [16] & $\begin{array}{l}\text { SLNB, preferably with double tracer technique (isotope }+ \\
\text { dye), and with at least } 3 \text { SLNs removed; in case of limited } \\
\text { axillary tumor load and a realistic chance of cN1 } \rightarrow \text { ycN0 } \\
\text { conversion, clipping the metastatic node before } \\
\text { neoadjuvant chemotherapy (NACT) is recommended }\end{array}$ & Not provided \\
\hline India [17] & No specific recommendation for $\mathrm{cN}+\mathrm{ycN} 0$ patients & Not provided \\
\hline Poland [18] & 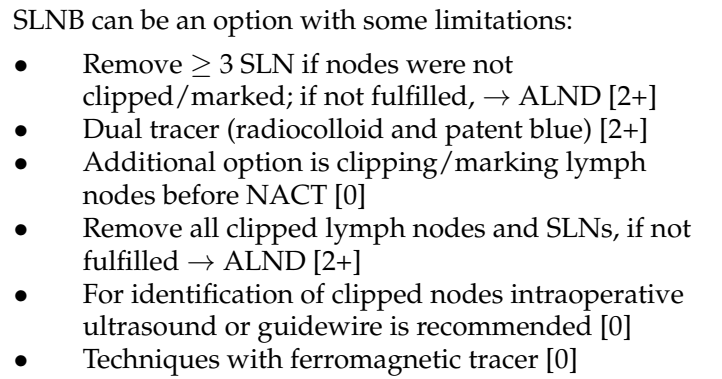 & $\begin{array}{l}\text { Power of recommendation in square } \\
\text { brackets (score }-2,-1,0,1+, 2+\text { ) }\end{array}$ \\
\hline
\end{tabular}

Last approved national guideline (2009) [19]: ALND is recommended, SLNB is not recommended after NACT New version proposed by the Romanian Society of Romania Obstetrics and Gynecology (2019; not approved by the Ministry of Health) [20]: Suspicious lymph nodes must be biopsied, and clipped if possible; if SLNB after NACT is attempted, dual tracer is recommended 
Table 2. Cont.

\begin{tabular}{|c|c|c|}
\hline National/International: & Staging Recommendation for $\mathrm{cN}+\rightarrow$ ycNo Patients & $\begin{array}{l}\text { Level of Evidence/Grade of } \\
\text { Recommendation }\end{array}$ \\
\hline \multicolumn{3}{|c|}{ Society Guidelines } \\
\hline $\begin{array}{c}\text { Denmark (Danish Breast Cancer Cooperative } \\
\text { Group) [22] }\end{array}$ & $\begin{array}{l}\text { TAD including double tracer technique (radioactive } \\
\text { tracer plus dye) } \\
\text { Target lymph node(s) to be marked with radioactive } \\
\text { iodine seeds or coils }\end{array}$ & Not provided \\
\hline $\begin{array}{l}\text { Italy (Assoziacione Italiana de Oncologica } \\
\text { Medica = AIOM) [23] }\end{array}$ & $\begin{array}{l}\text { SLNB; ALND omission may be considered in the case } \\
\text { one or more negative sentinel lymph nodes, identified } \\
\text { with double tracer and only in patients who were cN1/2 } \\
\text { at time of diagnosis }\end{array}$ & $\begin{array}{l}\text { Quality of evidence: Low } \\
\text { Strength of Recommendation: Weak }\end{array}$ \\
\hline Portugal (Portuguese Society of Senology) [24] & $\begin{array}{l}\text { cN1 patients should be clipped and ycN0 patients should } \\
\text { be managed by TAD, with omission of ALND in ypN0 if } \\
\text { the following criteria are fulfilled: (1) SLNB performed } \\
\text { using dual traced, }(2) \text { clipped node removed, and ( } 3) \\
\text { more than } 2 \text { removed nodes }\end{array}$ & Not provided \\
\hline $\begin{array}{l}\text { Russia (Association of Oncologists of Russia) } \\
\text { [25] }\end{array}$ & $\begin{array}{l}\text { It is recommended to mark the tumor before starting } \\
\text { neoadjuvant therapy to enable visualization during } \\
\text { subsequent surgical treatment. } \\
\text { If it is impossible to perform SLNB or if a metastatic } \\
\text { focus in the SLN is detected, it is recommended to } \\
\text { perform ALND. }\end{array}$ & $\begin{array}{l}\text { III, B } \\
\text { I, A }\end{array}$ \\
\hline $\begin{array}{l}\text { Spain (Spanish Society of Medical Oncology) } \\
\text { [26] }\end{array}$ & $\begin{array}{l}\text { ALND is recommended. In selected } \mathrm{cN}+\text { cases, in which } \\
\text { positive axillary node has been marked prior to NACT, } \\
\text { the identification and recovery of }>2 \text { negative SLNs } \\
\text { (including the marked node) with a double tracer } \\
\text { technique (Tc99 and methylene blue) may avoid ALND. }\end{array}$ & $\begin{array}{l}\text { I, A } \\
\text { II, C }\end{array}$ \\
\hline
\end{tabular}

Table 3. Studies on sentinel node biopsy after neoadjuvant therapy in initially node-positive patients.

\begin{tabular}{ccccc}
\hline Study & Number of Patients & $\begin{array}{c}\text { Preoperative Axillary } \\
\text { Assessment }\end{array}$ & $\begin{array}{c}\text { Detection Rate of the } \\
\text { Sentinel Node }\end{array}$ & False Negative Rate \\
\hline SENTINA [4] & 592 & $\begin{array}{c}\text { Clinical examination, } \\
\text { ultrasound }\end{array}$ & $80.1 \%$ & $14.2 \%$ \\
\hline SN FNAC [27] & 153 & $\begin{array}{c}\text { Clinical examination, } \\
\text { ultrasound }\end{array}$ & $8.4 \% 1$ \\
\hline ACOSOG Z1071 [5] & 649 & $\begin{array}{c}\text { Surgical approach } \\
\text { independent of clinical } \\
\text { response }\end{array}$ & $92.9 \%$ & $12.6 \%{ }^{2}$ \\
\hline GANEA 2 [1] & 307 & $\begin{array}{c}\text { Surgical approach } \\
\text { independent of clinical } \\
\text { response }\end{array}$ & $79.8 \%$ & $11.9 \%$ \\
\hline Meta-analysis [6] & 3398 & - & $91 \%$ & $13 \%$ \\
\hline
\end{tabular}

${ }^{1}$ Sentinel nodes with isolated tumor cells [ypN0(i+)] defined as positive. ${ }^{2}$ Only in patients with at least 2 sentinel nodes removed (pre-defined study criterion); in case of only one sentinel node removed, the false negative rate was $29.3 \%$ [7].

In order to shed light on this much debated topic, the European Breast Cancer Research Association of Surgical Trialists (EUBREAST) has initiated AXSANA (AXillary Surgery After NeoAdjuvant Treatment), a multinational prospective cohort study (NCT04373655) which enrolls $\mathrm{cN}+$ patients undergoing NACT who convert to ycN0. The aim of AXSANA is to assess the impact of different surgical staging procedures in the axilla on the oncologic outcome and on health-related quality of life. 


\section{Targeted Axillary Dissection: More Questions Open Than Answered}

\subsection{Which Marking Technique Is Optimal?}

So far, several methods for marking of target lymph node(s) have been developed, usually based on techniques that are already in use for the localization of non-palpable breast lesions (Table 4). Interestingly, there are notable regional differences regarding the use of various techniques. The same method may be the technique of choice in one country, while being completely unknown in another.

Table 4. Possible options for marking and localizing suspicious lymph nodes prior to start of neoadjuvant chemotherapy (modified after Reference [12]).

\begin{tabular}{|c|c|c|c|}
\hline Marking & Localization & Advantages & Disadvantages \\
\hline Clip & $\begin{array}{ll}\text { - } & \text { Preoperative } \\
\text { imaging-guided wire } \\
\text { localization (mostly } \\
\text { ultrasound-guided) } \\
\text { Intraoperative ultrasound } \\
\text { - } \quad \text { Preoperative placement of a } \\
\text { radioactive/magnetic seed, } \\
\text { radar marker, or ink into the } \\
\text { clipped area (mostly } \\
\text { ultrasound-guided) }\end{array}$ & $\begin{array}{ll}\text { - } & \text { Largest amount of data } \\
\text { - } & \text { Reliable radiographic } \\
\text { - } & \text { visibility } \\
\text { - } & \text { No radioactivity involved } \\
& \text { Relatively low cost }\end{array}$ & $\begin{array}{l}\text { Visibility on ultrasound varies widely } \\
\text { between studies, and a large part of the } \\
\text { axilla is not visible on a mammogram } \\
\text { Preoperative localization necessary } \\
\text { (wire/seed) unless intraoperative } \\
\text { ultrasound is used } \\
\text { Results from studies comparing different } \\
\text { clips not yet available } \\
\text { Relatively low detection rate (rate of } \\
\text { successful target lymph node (TLN) } \\
\text { removal 70\% in the largest available } \\
\text { dataset [28]) } \\
\text { Visibility of some clips (e.g., hydrogel } \\
\text { clips) may decrease over time } \\
\text { Reaction of the node tissue to the clip } \\
\text { (especially hydrogel-containing clips) } \\
\text { may be misinterpreted on pathological } \\
\text { examination } \\
\text { Some clips approved explicitly for } \\
\text { marking in the breast, not in the axilla } \\
\text { Allergic reactions rare but possible } \\
\text { (some titanium clips contain nickel) }\end{array}$ \\
\hline Radioactive seed & $\begin{array}{l}\text { Intraoperative localization using } \\
\text { gamma probe }\end{array}$ & $\begin{array}{ll}\text { - } & \text { High detection rate } \\
\text { No preoperative wire } \\
\text { localization necessary } \\
\text { Transcutaneous localization } \\
\text { before skin incision possible }\end{array}$ & $\begin{array}{l}\text { - Procedure not authorized in some } \\
\text { countries, requires complex radiation } \\
\text { safety procedures } \\
\text { Signal reduction over time (i.e., in case of } \\
\text { longer chemotherapy due to } \\
\text { interruptions) } \\
\text { - } \quad \text { High cost } \\
\text { Allergic reactions rare but possible } \\
\text { (some seeds contain nickel) }\end{array}$ \\
\hline Carbon suspension & Intraoperative visualization & $\begin{array}{ll}\text { - } & \text { No preoperative wire } \\
& \text { localization necessary } \\
\text { - } & \text { No radioactivity involved } \\
\text { - } & \text { Low cost }\end{array}$ & $\begin{array}{l}\text { - } \quad \text { Limited data } \\
\text { - } \quad \text { Marking cannot be localized without } \\
\text { surgical exploration of the axilla } \\
\text { - } \quad \text { Possible ink migration } \\
\text { - } \quad \text { In cassible bluin discoloration } \\
\text { ink colors must if used for SLNB, the }\end{array}$ \\
\hline Magnetic seed & $\begin{array}{l}\text { Intraoperative localization using } \\
\text { magnetic probe }\end{array}$ & $\begin{array}{ll}\text { - } & \text { No preoperative wire } \\
\text { localization necessary } \\
\text { - } \quad \text { No radioactivity involved } \\
\text { Transcutaneous localization } \\
\text { before skin incision possible }\end{array}$ & $\begin{array}{l}\text { - } \quad \text { Very limited data } \\
\text { Concerns regarding use in patients with } \\
\text { pacemakers and implantable } \\
\text { defibrillators } \\
\text { - Standard metal surgical tools should not } \\
\text { be used during measurement } \\
\text { - } \begin{array}{l}\text { Allergic reactions rare but possible } \\
\text { despite very low nickel content }\end{array} \\
\text { - } \quad \text { MRI artifacts } \\
\text { - } \\
\text { High cost } \\
\text { Localization in deep tissue may result in } \\
\text { weaker signal (recommended depth max. } \\
3.5 \mathrm{~cm} \text { ) }\end{array}$ \\
\hline
\end{tabular}


Table 4. Cont.

\begin{tabular}{|c|c|c|c|}
\hline Marking & Localization & Advantages & Disadvantages \\
\hline $\begin{array}{c}\text { Radar reflector } \\
\text { localization (RRL) }\end{array}$ & $\begin{array}{l}\text { Intraoperative localization using } \\
\text { radar locator }\end{array}$ & $\begin{array}{ll}\text { - } & \text { No preoperative wire } \\
\text { - } & \text { localization necessary } \\
\text { - } & \text { Transcutaneous localization } \\
\text { before skin incision possible }\end{array}$ & $\begin{array}{ll}\text { - } & \text { Very limited data } \\
\text { - } & \text { High cost } \\
\text { Allergic reactions rare but possible } \\
\text { (some markers contain nickel) } \\
\text { - } \quad \text { Minimal MRI artifacts possible } \\
\text { Interference with older halogen lights in } \\
\text { the operating theatre possible } \\
\text { - Adequate localization may be limited in } \\
\text { case of a large distance between marker } \\
\text { and detection probe }\end{array}$ \\
\hline $\begin{array}{c}\text { Radiofrequency } \\
\text { identification } \\
\text { devices (RFID tags) }\end{array}$ & $\begin{array}{l}\text { Intraoperative localization using } \\
\text { radiofrequency localizer }\end{array}$ & $\begin{array}{ll}\text { - } & \text { No preoperative wire } \\
\text { - } & \text { Nocalization necessary } \\
\text { - } \quad \text { No decrease of signal over } \\
\text { time } \\
\text { - Transcutaneous localization } \\
\text { before skin incision possible }\end{array}$ & $\begin{array}{l}-\quad \text { Very limited data } \\
-\quad \text { High cost } \\
\text { - } \quad \text { Conc artifacts possible } \\
\text { pacemakers and implantable } \\
\text { defibrillators }\end{array}$ \\
\hline
\end{tabular}

To date, the largest amount of data has been published on clip-based targeted axillary dissection (TAD). Unless intraoperative ultrasound is used, this strategy requires a preoperative localization step, performed either by the use of a wire or by placing another marker (e.g., magnetic or radioactive seed, radar marker or radiofrequency identification [RFID] tag) into the clipped area that will allow identification during surgery. Still, the success of target lymph node (TLN) removal depends on the ultrasound visibility of the clip inserted before NACT.

The study that brought international attention to the technique was a retrospective analysis of a prospective database at the M.D. Anderson Cancer Center (Table 5) [8]. Nearly all patients in this study underwent ultrasound-guided placement of a radioactive iodine125 seed into the previously clipped node prior to surgery. This strategy offers more flexibility than wire localization, which was used in two patients only, because the seed can be inserted several days before surgery, whereas the wire placement is usually scheduled for the morning before the operation or (rarely) the day before. The study by Caudle et al. showed that the FNR of TAD can be as low as $2.0 \%$ [8]. However, since only patients with successful preoperative localization were included in this analysis, it is unclear whether the clip could not be visualized in some patients, making preoperative localization impossible.

Table 5. Marking and localization methods for target lymph node retrieval in breast cancer patients undergoing neoadjuvant chemotherapy.

\begin{tabular}{|c|c|c|c|c|c|c|}
\hline $\begin{array}{l}\text { Marking } \\
\text { Technique } \\
\text { before } \\
\text { NACT }\end{array}$ & Trial & Number of Patients & Localization Technique & $\begin{array}{l}\text { Preoperative or } \\
\text { Intraoperative } \\
\text { Detection Rate of } \\
\text { the Marker }\end{array}$ & $\begin{array}{c}\text { Successful TLN } \\
\text { Removal }\end{array}$ & FNR $^{1}$ \\
\hline \multirow{4}{*}{ Clip } & SENTA $[28,29]$ & 473 & $\begin{array}{l}\text { Preoperative wire } \\
\text { localization in most } \\
\text { patients }\end{array}$ & Ultrasound: $89 \%$ & $78 \%$ & $\begin{array}{l}\text { TAD: } 4.3 \% \\
\text { TLNB: } 7.2 \%\end{array}$ \\
\hline & Caudle 2016 [8] & 208 & $\begin{array}{l}\text { Preoperative radioactive } \\
\text { seed placement into the } \\
\text { clipped area } \rightarrow \\
\text { intraoperative detection } \\
\text { using gamma probe }\end{array}$ & NR & $98 \%^{2}$ & $\begin{array}{l}\text { Clipped node } \\
\text { removal: } 4.2 \%^{3} \\
\text { Clipped node } \\
\text { removal + SLNB: } \\
2.0 \% \text { SLNB alone: } \\
10.1 \%\end{array}$ \\
\hline & $\begin{array}{c}\text { ACOSOG Z1071 } \\
{[5,7]}\end{array}$ & 203 & None & NR & $83 \%{ }^{4}$ & $\begin{array}{l}\text { SLNB: } \\
6.8 \% \text { if TLN was } \\
\text { SLN } \\
19 \% \text { if TLN was not } \\
\text { SLN }^{5}\end{array}$ \\
\hline & $\begin{array}{l}\text { Plecha } 2015 \text { [30] (in } \\
\text { 98\% HydroMARK } \\
\text { clip) }\end{array}$ & 91 & $\begin{array}{l}\text { Wire localization in } 74 \% \text { of } \\
\text { patients }\end{array}$ & NR & $\begin{array}{l}97 \% \text { in patients with } \\
\text { and } 83 \% \text { in patients } \\
\text { without wire } \\
\text { localization }\end{array}$ & NR \\
\hline
\end{tabular}


Table 5. Cont.

\begin{tabular}{|c|c|c|c|c|c|c|}
\hline $\begin{array}{c}\text { Marking } \\
\text { Technique } \\
\text { before } \\
\text { NACT }\end{array}$ & Trial & Number of Patients & Localization Technique & $\begin{array}{c}\text { Preoperative or } \\
\text { Intraoperative } \\
\text { Detection Rate of } \\
\text { the Marker }\end{array}$ & $\begin{array}{l}\text { Successful TLN } \\
\text { Removal }\end{array}$ & FNR $^{1}$ \\
\hline & Laws 2020 [31] & 57 & $\begin{array}{l}\text { Preoperative placement of } \\
\text { a magnetic seed, a RRL clip } \\
\text { or a RFID tag into the } \\
\text { clipped area }\end{array}$ & $98 \%$ & $89 \%$ & NR \\
\hline & Ngyuen 2017 [32] & 56 & $\begin{array}{l}\text { Preoperative radioactive } \\
\text { seed placement } \rightarrow \\
\text { intraoperative detection } \\
\text { using gamma probe }\end{array}$ & Ultrasound: $72 \%$ & $91 \%$ & NR \\
\hline & Simons 2021 [33] & 50 & $\begin{array}{l}\text { Preoperative magnetic } \\
\text { seed placement } \rightarrow \\
\text { intraoperative detection } \\
\text { using magnetic probe }\end{array}$ & Ultrasound: $100 \%$ & $98 \%$ & NR \\
\hline & $\begin{array}{l}\text { ILINA trial [34] } \\
\text { (HydroMARK clip) }\end{array}$ & 46 & Intraoperative ultrasound & Ultrasound: $96 \%$ & NR & TAD: $4.1 \%^{3}$ \\
\hline & Sun 2020 [35] & 38 & $\begin{array}{l}\text { Preoperative RRL clip } \\
\text { placement } \rightarrow \\
\text { intraoperative detection } \\
\text { using radar probe }\end{array}$ & $100 \%$ & $100 \%$ & NR \\
\hline & $\begin{array}{l}\text { Hartmann } 2018 \text { [36] } \\
\text { (HydroMARK clip) }\end{array}$ & 30 & $\begin{array}{l}\text { Wire localization in } 80 \% \text { of } \\
\text { patients }(67 \% \text { US, } 13 \% \\
\text { mammography) }\end{array}$ & Ultrasound: $83 \%$ & $\begin{array}{l}70 \% \text { in the entire } \\
\text { cohort, } 83 \% \text { in } \\
\text { patients with wire } \\
\text { localization }\end{array}$ & $0 \%$ \\
\hline & Diego 2016 [37] & 30 & $\begin{array}{l}\text { Preoperative radioactive } \\
\text { seed placement into the } \\
\text { clipped area } \rightarrow \\
\text { intraoperative detection } \\
\text { using gamma probe }\end{array}$ & Ultrasound: $93 \%$ & $93 \%$ & NR \\
\hline & $\begin{array}{c}\text { Mariscal Martinez } \\
2021 \text { [38] } \\
\text { (HydroMARK 93\%, } \\
\text { Tumark 3\%, } \\
\text { UltraCor-Twirl 3\%) }\end{array}$ & 29 & $\begin{array}{l}\text { Preoperative magnetic } \\
\text { seed placement } \rightarrow \\
\text { intraoperative detection } \\
\text { using magnetic probe }\end{array}$ & $100 \%$ & $100 \%$ & $\begin{array}{l}\text { SLNB alone: } 21.4 \% \\
\text { TAD: } 5.9 \%\end{array}$ \\
\hline & $\begin{array}{l}\text { Kim } 2019 \text { [39] } \\
\text { (UltraClip) }\end{array}$ & 28 & $\begin{array}{l}\text { US-guided injection of ink } \\
\text { and skin marking }\end{array}$ & $\begin{array}{l}\text { Ultrasound: } 79 \% \\
\text { clearly visible, } 21 \% \\
\text { equivocally visible }\end{array}$ & $96 \%$ & NR \\
\hline & $\begin{array}{c}\text { Balasubramanian } \\
2020 \text { [40] } \\
\text { (HydroMARK clip) }\end{array}$ & 25 & Wire localization & NR & $92 \%$ & NR \\
\hline & Lim $2020[41,42]$ & 14 & $\begin{array}{l}\text { Preoperative US-guided } \\
\text { skin marking }\end{array}$ & NR & $\begin{array}{l}84 \% \\
\text { (UltraCor Twirl: } \\
100 \% \\
\text { HydroMARK: 78\% } \\
\text { UltraClip } \\
\text { DualTrigger: } 50 \% \\
\text { UltraClip: } 0 \% \text { ) }\end{array}$ & $\begin{array}{l}\text { TLNB: } \\
0 \% \text { if } \geq 2 \text { marked } \\
\text { nodes were } \\
\text { removed } \\
7.1 \% \text { if only first } \\
\text { TLN was removed }\end{array}$ \\
\hline \multirow{2}{*}{$\begin{array}{l}\text { Radioactive } \\
\text { seed }\end{array}$} & RISAS [43] & 227 & $\begin{array}{l}\text { Gamma probe } \\
\text { (intraoperative) }\end{array}$ & NR & $98 \%$ & TAD: $3.5 \%$ \\
\hline & Donker 2015 [44] & 100 & $\begin{array}{l}\text { Gamma probe } \\
\text { (intraoperative) }\end{array}$ & $\begin{array}{l}100 \% \text { (gamma } \\
\text { probe) }\end{array}$ & $97 \%$ & TLNB: $7 \%^{3}$ \\
\hline $\begin{array}{l}\text { Magnetic } \\
\text { seed }\end{array}$ & Thill 2020 [45] & 5 & $\begin{array}{l}\text { Magnetic probe } \\
\text { (intraoperative) }\end{array}$ & $100 \%$ & $100 \%$ & NR \\
\hline $\begin{array}{l}\text { Radar } \\
\text { reflector } \\
\text { localization- } \\
\text { clip }\end{array}$ & Sun 2020 [35] & 7 & $\begin{array}{l}\text { Intraoperative radar } \\
\text { localization }\end{array}$ & $100 \%$ & $100 \%$ & NR \\
\hline RFID tag & Malter 2020 [46] & 10 & $\begin{array}{l}\text { Radiofrequency probe } \\
\text { (intraoperative) }\end{array}$ & $100 \%$ & $100 \%$ & NR \\
\hline \multirow{3}{*}{$\begin{array}{c}\text { Carbon } \\
\text { suspension }\end{array}$} & Hartmann 2020 [47] & 118 & $\begin{array}{l}\text { Intraoperative } \\
\text { visualization }\end{array}$ & $94 \%$ & $94 \%$ & TAD: $9.1 \%$ \\
\hline & $\begin{array}{c}\text { Natsiopoulos } 2019 \\
{[48]}\end{array}$ & 75 & $\begin{array}{l}\text { Intraoperative } \\
\text { visualization }\end{array}$ & $100 \%$ & $100 \%$ & NR \\
\hline & Allweis [49] & 63 & $\begin{array}{l}\text { Intraoperative } \\
\text { visualization }\end{array}$ & $95 \%$ & $95 \%$ & NR \\
\hline
\end{tabular}


Table 5. Cont.

\begin{tabular}{|c|c|c|c|c|c|c|}
\hline $\begin{array}{c}\text { Marking } \\
\text { Technique } \\
\text { before } \\
\text { NACT }\end{array}$ & Trial & Number of Patients & Localization Technique & $\begin{array}{l}\text { Preoperative or } \\
\text { Intraoperative } \\
\text { Detection Rate of } \\
\text { the Marker }\end{array}$ & $\begin{array}{c}\text { Successful TLN } \\
\text { Removal }\end{array}$ & FNR $^{1}$ \\
\hline & Khallaf 2020 [50] & 20 & $\begin{array}{l}\text { Intraoperative } \\
\text { visualization }\end{array}$ & $95 \%$ & $95 \%$ & $\begin{array}{c}\text { TAD: } 8.3 \% \\
\text { SLNB alone: } 15.3 \%\end{array}$ \\
\hline & Gatek 2020 [51] & 20 & $\begin{array}{l}\text { Intraoperative } \\
\text { visualization }\end{array}$ & $100 \%$ & $100 \%$ & NR \\
\hline & Choy 2014 [52] & 12 & $\begin{array}{l}\text { Intraoperative } \\
\text { visualization }\end{array}$ & $100 \%$ & $100 \%$ & NR \\
\hline
\end{tabular}

${ }^{1}$ Analyzed only in patients receiving ALND. ${ }^{2}$ The clip was absent on postoperative axillary radiography in the remaining five patients, suggesting clip dislodgement. ${ }^{3}$ Lymph nodes with isolated tumor cells were considered positive. ${ }^{4}$ In the remaining $17 \%$ of patients, the clip was neither in the SLN nor in the ALND specimen. ${ }^{5}$ Only in patients with $\geq 2$ SLNs removed and initially cN1. Abbreviations: ALND—axillary lymph node dissection, FNR—false-negative rate, MARI—marking the axillary lymph node with radioactive iodine $\left({ }^{125}\right.$ I) seeds, NACT—neoadjuvant chemotherapy, NR—not reported, RFID—radiofrequency identification device, RRL—radar reflector localization, SLNB—sentinel lymph node biopsy, SLN—sentinel lymph node, TAD—-targeted axillary dissection (removal of marked node and SLN), TLN—target lymph node, TLNB—target lymph node biopsy, US—ultrasound.

The results of the prospective German multicenter SENTA register study were presented at the ESMO conference in 2019 and are now available as a full publication [28,29]. In this study, the TLN was clipped before NACT in 473 patients. A Tumark Vision clip (SOMATEX®, Berlin, Germany) was used in the majority of cases $(71 \%)$, followed by an O-Twist clip (BIP, Türkenfeld, Germany) (12\%). Clip types used in the remaining patients have not been described. In 50 out of 473 patients, a targeted lymph node biopsy (TLNB) was not attempted either because the clip was not visible upon preoperative ultrasound or TLNB was for some reason not planned by the investigator. The TLN could be successfully removed in 329 of 423 patients, mostly after wire localization, resulting in an overall removal rate of $78 \%$ among patients in whom a TLNB/TAD was attempted. The TLN detection rates were higher in case a Tumark Vision or a O-Twist clip was used, compared to other clips $(79.7 \%, 78.4 \%, 69.4 \%$, respectively). Interestingly, triple negativity and high Ki67 index were associated with TLNB failure (i.e., TLN not removed during TLNB attempt). In $63 \%$ of patients, the SLN and the TLN were identical. In the subgroup of 278 patients who received ALND, TLNB alone and TAD resulted in FNRs of $7.2 \%$ and $4.3 \%$, respectively.

Another marking method is the injection of a small volume $(0.1-0.5 \mathrm{~mL})$ of a carbon solution into the suspicious lymph node. At surgery, the TLN is identified visually by its dark staining. The results of TATTOO, the largest prospective trial on carbon solution-based $\mathrm{TAD}$, have been presented recently [47]. In $94 \%$ of 118 included patients, the marked node could be detected intraoperatively. In $60 \%$ of cases, SLN and TLN were identical. In 5 $(4.5 \%)$ patients, unintentional tattooing of the skin was observed, but it remains unclear whether this effect is permanent. In $61 \mathrm{cN}+$ patients converting to ycN0, completion ALND was performed. In this subgroup, three out of 33 patients with residual axillary disease had not been correctly identified by TAD, resulting in a FNR of $9.1 \%$. A similar FNR of 8.3\% was reported from the only other study on FNR in carbon solution-based TAD [50].

The MARI technique ("Marking the Axillary lymph node with Radioactive Iodine seeds") was reported from the Netherlands in 2015 [44]. It implies that a titaniumencapsuled radioactive seed is inserted into the suspicious lymph node before NACT under ultrasound guidance. In contrast to technetium-99-based localization of non-palpable breast lesions before primary surgery, the longer half-life (59 days) of iodine-125 allows for use in the neoadjuvant setting. Donker et al. evaluated the MARI technique in 100 patients scheduled for NACT [44]. Marking of the biopsy-proven positive lymph node and the breast tumor using identical seeds was conducted at one procedure. In three patients, the seed could not be properly positioned in the lymph node, resulting in a removal rate of the biopsied node of $97 \%$. No relevant loss of signal was observed after a median NACT duration of 17 weeks, and all seeds could be removed successfully. Importantly, no SLNB was performed in this study, and thus the reported FNR of 7\% refers to the TLNB alone.

Two aspects have been critically discussed after the introduction of the MARI technique. First, the procedure requires complex safety regulations and cannot be performed 
in some countries due to national radiation protection laws. Secondly, both the localization of iodine-125 and technetium-99 used for SLN mapping require a gamma probe so interference might potentially occur in case of down-scatter of technetium-99m into the energy spectrum of iodine-125. The first results of the RISAS trial (NCT02800317), presented by Simons et al. at the San Antonio Breast Cancer Symposium in 2020 [53], could, however, show that the combination of the MARI technique and SLNB is feasible: TAD was successfully performed in 223 out of 227 (98\%) patients. The trial was designed to test the non-inferiority of TAD over ALND, with FNR as the main endpoint. Non-inferiority was assumed if the upper bound of a 95\% confidence interval around the FNR was lower than $6.25 \%$. Although the FNR was low (3.5\%), the prespecified primary endpoint was not met (95\% confidence interval 1.38-7.16). The authors reported, however, that 4 out of 5 patients with a false-negative result (i.e., residual lymph node metastasis in the ALND specimen despite tumor-free TAD) were found among the first 10 enrolled patients of participating institutions, suggesting a learning curve that should be considered when planning future studies.

Another technique to mark a biopsy-proven lymph node metastasis is based on the placement of a magnetic seed. So far, the only magnetic seed for axillary node marking evaluated in studies is the MagSeed ${ }^{\circledR}$ (Endomag, London, United Kingdom). The seed is detected during surgery by using a magnetic probe called Sentimag ${ }^{\circledR}$ (Endomag, London, United Kingdom) surgical guidance platform. This method has already provided evidence for the successful resection of non-palpable breast lesions [54]. Its use for TAD was restricted by the initial requirement to remove seeds within 30 days after placement, but recently, both the Food and Drug Administration (FDA, 2018) and the Conformite Européenne (CE) marking (2020) approved long-term implantation in any soft tissue, thus allowing use in the neoadjuvant setting. First data on the magnetic seed-based TAD have been recently published by Thill et al. [45]. This small study showed a detection rate of $100 \%$. Since magnetic seeds can lead to large magnetic resonance imaging (MRI) artifacts, it should be used with caution in patients in whom MRI-based assessment of response during NACT is planned.

Other possible techniques are radar reflector-localization clips [55] and radiofrequency identification (RFID) tags [56,57], that have provided promising results for non-palpable lesion localization, while data on lymph node marking are limited. Table 4 shows potential advantages and disadvantages of various methods and Table 5 gives an overview of current evidence.

\subsection{How Many Nodes Should Be Marked?}

Since TAD is a relatively new technique that still needs to be validated and standardized, various institutions follow different strategies. So far, there is no consensus on the number of nodes that should be marked in patients with more than one suspicious lymph node on imaging. While most studies report the marking of a single node, it is unclear which lymph node was selected for biopsy and marking in these cases. Options vary between the largest, the "most suspicious", or the best accessible lymph node [8,47]. Other authors report marking of all suspicious nodes [42,48]. Both strategies offer their own advantages and disadvantages (Table 6).

Regarding the accuracy of lymph node assessment, marking only one axillary lymph node in case of patients with several suspicious or biopsy-proven nodes might increase the FNR since the marked lymph node might be free of tumor while other previously suspicious but not marked lymph nodes may still contain tumor residuals and remain in situ. A heterogenous axillary response to NACT is common and can be diagnosed in up to $74 \%$ of patients with hormone receptor-positive HER2-negative disease, followed by $29 \%$ in triple-negative and 25\% in HER2-positive tumors [58]. Lim et al. conducted a small study with a complex design to explore FNRs of different TLNB strategies in the same set of patients [42]. All suspicious nodes of a patient were marked with different types of clips to aid individual node identification (e.g., UltraCor Twirl, HydroMARK, and UltraClip). 
Altogether, 21 nodes in 14 patients were clipped. After NACT, all patients received TLNB and ALND. The first clipped node alone had a FNR of $7.1 \%$, which sank to $0 \%$ when the second clipped node was taken into account. No SLNB was performed, and it remains unclear how this might have influenced the FNR.

Table 6. Potential strategies regarding the number of marked nodes.

\begin{tabular}{|c|c|c|}
\hline & Only One Node Is Marked & All Suspicious Nodes Are Marked \\
\hline Advantages & $\begin{array}{ll}\text { - } & \text { Lower cost } \\
\text { - } & \text { Fewer nodes are removed at } \\
\text { surgery } \rightarrow \text { possibly less arm } \\
\text { morbidity } \\
\text { - } \quad \text { Less challenging marking } \\
\text { procedure }\end{array}$ & $\begin{array}{l}\text { - Lower FNR in small studies } \\
\rightarrow \text { possibly better oncological } \\
\text { outcome }\end{array}$ \\
\hline Disadvantages & $\begin{array}{l}\text { - Heterogenous response of } \\
\text { different nodes to therapy } \rightarrow \\
\text { higher FNR } \rightarrow \text { possibly higher } \\
\text { recurrence rate }\end{array}$ & 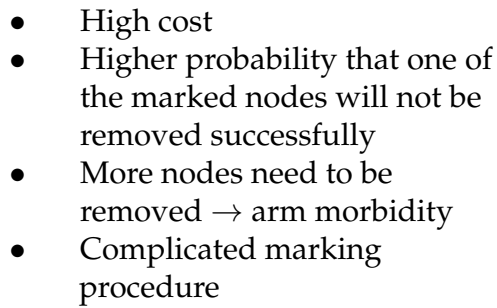 \\
\hline
\end{tabular}

Concerning arm morbidity, marking all suspicious nodes will necessarily result in removal of more lymph nodes. Natsiopoulos et al. conducted carbon solution-based TAD (Spot ${ }^{\circledR}$, GI Supply, Inc., Mechanicsburg, PA, USA) in 75 patients [48], marking each biopsy-proven or strongly suspicious node (median 2, range 1-5). At surgery, 2-10 nodes (median 4) were retrieved. How this relatively high number of removed nodes may affect quality of life and arm morbidity remains to be clarified. Importantly, a clinically relevant balance between high accuracy (more extensive staging) and low morbidity (less extensive staging) must be found.

\subsection{When Should Lymph Nodes Be Marked?}

To date, there is no consensus on the optimal timepoint of marker placement. In most studies, lymph node metastases were confirmed by fine needle aspiration or core biopsy. Such procedures, however, are not standard in some countries, and not all guidelines recommend routine minimally invasive biopsy in case of suspicious findings. Especially in case of large tumors and multiple highly suspicious nodes, clinicians may find it sufficient to perform biopsy of the breast tumor only.

If a minimally invasive biopsy is performed, the marker may be inserted into the same lymph node(s) at the same session or at a second session upon confirmation of metastasis by pathology/cytology. Data on this aspect lack detail in available studies but most authors report the placement of the marker into the "previously proven" node $[44,48]$. In contrast, marking of the suspicious lymph node immediately after the biopsy is reported by others [31,52]. Table 7 provides an overview of advantages and disadvantages of both strategies.

\subsection{What to Do in Case of a "Lost Marker"?}

A major concern expressed by clinicians trying to implement TAD at their institutions is the uncertainty of how to deal with patients in whom the marker has not been retrieved at surgery. Since a TAD/TLNB cannot be successfully performed in these patients, completion ALND is an obvious choice. Still, in some patients, the marker will not be found in the ALND specimen either. The pivotal study by Caudle et al. included 208 patients whose metastatic nodes were clipped prior to NACT [8]. In five of these patients, the clip could neither be identified in the surgical specimen nor upon radiography of the axilla, suggesting 
clip dislodgement. In another study, the clip could not be retrieved in two out of 73 patients, but no further details were reported [30]. To date, the management of patients with lost clips is unclear.

Table 7. Potential strategies regarding the time point of lymph node marking.

\begin{tabular}{lll}
\hline At Time of Biopsy & $\begin{array}{l}\text { After Pathological/Cytological } \\
\text { Confirmation of Nodal Metastasis }\end{array}$ \\
\hline Advantages & $\begin{array}{l}\text { Only one invasive procedure } \\
\text { for the patient } \\
\text { Certainty that the marking has } \\
\text { been placed into the biopsied } \\
\text { node }\end{array}$ & $\begin{array}{l}\text { The marker is placed only if } \\
\text { necessary, i.e., in case a } \\
\text { TLNB/TAD is planned }\end{array}$ \\
\hline Disadvantages & $\begin{array}{l}\text { Some lymph nodes might be } \\
\text { marked unnecessarily } \rightarrow \\
\text { higher cost }\end{array}$ & $\begin{array}{l}\text { In case of several suspicious } \\
\text { nodes, the marker may be } \\
\text { placed into the one that has } \\
\text { not been biopsied } \\
\text { In case of reactive lymph } \\
\text { nodes due to biopsy, the } \\
\text { marker may be placed into a } \\
\text { benign node } \\
\text { An additional invasive } \\
\text { procedure is necessary }\end{array}$ \\
\hline
\end{tabular}

In case of other markers, several additional concerns need to be addressed. Since leaving radioactive seeds behind results in a major radiation regulation breech that must be reported to regulation authorities, seed explantation should be attempted whenever possible unless it would jeopardize patient's well-being [59]. In case of magnetic seeds, no radioactivity is involved, but leaving a magnetic marker in the axilla can result in large MRI artifacts and thus compromise imaging assessment during post-treatment surveillance. Minor MRI artifacts are also possible in case of unsuccessful radar marker or RFID tag retrieval.

While lost clips can only be removed using imaging-guidance (usually radiography, ultrasound, or computer tomography), radioactive and magnetic seeds as well as radar markers and RFID tags can be identified using a special probe and carbon ink-marked nodes can only be visualized intraoperatively during dissection of the axilla, possibly resulting in different radicality of retrieval procedure and individual risk faced by the patient.

\subsection{Is TAD Safe for All Patients?}

It is yet unclear whether all $\mathrm{cN}+$ patients can safely omit completion ALND in case of negative axillary staging. So far, while none of the studies on TAD have reported oncological outcome or health-related quality of life, there is limited information available on SLNB alone in this setting. Kahler-Ribeiro-Fontana et al. have recently reported on long-term outcomes following SLNB after NACT [3]. Among 222 clinically node-positive patients, 123 had no residual axillary disease at surgery. Of these, only two patients $(1.6 \%)$ developed axillary recurrence after 3.6 and 5.5 years from surgery and were alive without disease at the last follow-up. Among all cN1/2 patients, no significant differences in 5-year and 10-year overall survival were found between patients who received ALND and those in whom ALND was omitted.

Most TAD validation studies include heterogeneous groups of patients. In the pivotal study by Caudle et al., nearly all patients had cT1-cT3 tumors, but $28 \%$ of patients presented with at least four abnormal nodes on ultrasound [8]. Similarly, in the largest study on carbon solution-based TAD, $25 \%$ of patients had $\geq 4$ and $4 \%$ had $\geq 10$ suspicious nodes before NACT [47]. 124 out of $423(29 \%)$ patients enrolled in the SENTA trial had at least three abnormal nodes [29]. Intuitively, the more nodes appear suspicious on initial 
ultrasound, the more probable it is for the TAD to miss residual disease, especially in case only one node was marked, thus resulting in a higher FNR [60].

Other factors that can improve identification of patients who do not benefit from completion ALND are breast response to therapy and tumor subtype. A multivariable analysis of 13,396 patients showed that pathological complete response $(p C R) n$ the breast was the most important predictor of $\mathrm{pCR}$ in the axilla (odds ratio 20.37 for yT0) [61]. Other studies reported a strong association between response in the breast and in the axilla, particularly in patients with HER2-positive and triple-negative breast cancer [62-64], implying that tumor subtype should probably also be implemented into a potential decision algorithm. Since patients with HER2-positive and triple-negative cancer achieving radiological breast response have the highest probability of reaching axillary $\mathrm{pCR}$, they are probably most likely to benefit from de-escalation of surgical treatment, such as TAD.

\subsection{Beyond Surgical Therapy: Which Fields Should Be Irradiated after TAD?}

Another controversial issue is the target volume for nodal irradiation. While some guidelines exclude levels I and II from irradiation in case of a negative TAD, others suggest to cover all regions if they have not been assessed with a therapeutic intent. More specifically, it remains unclear whether patients with an extensive axillary tumor burden who achieve $\mathrm{pCR}$ after NACT benefit from additional regional treatment.

Koolen et al. from the Netherlands Cancer Institute proposed a hypothetical algorithm based on initial nodal status and response to NACT [65]. In this algorithm, patients receive not only ultrasound but also PET-CT prior to NACT. Those with 1-3 positive nodes are recommended no further axillary therapy in case of axillary pCR, defined as a negative MARI procedure (i.e., resection of a radioactive seed-marked TLN) [44]. In case of non-pCR, axillary radiotherapy is performed. For patients with $\geq 4$ positive nodes before NACT, axillary radiotherapy is always indicated but patients with non-pCR are also recommended an ALND. In a cohort of 100 patients treated by TLNB (MARI) and ALND, the proposed algorithm would have led to omission of ALND in 74\%, and some patients potentially risk under- $(3 \%)$ or over-treatment (17\%) [65]. Whether such tailored strategies might be an acceptable compromise between high oncological safety on one side and lower arm morbidity on the other remains to be clarified in future trials. In this context, the results of the NSABP-B51 trial (NCT01872975) are expected to be published in 2023. This phase III clinical trial is designed to test whether regional nodal irradiation (RNI) improves the recurrence-free interval rate in women with $\mathrm{cN} 1$ breast cancer before NACT who become pathologically node-negative at the time of surgery. Patients who undergo mastectomy are randomly assigned to observation or radiotherapy to the chest wall and undissected axilla, internal mammary nodes, and ipsilateral supraclavicular fossa, whereas women who undergo breast-conserving surgery are randomized to adjuvant whole breast irradiation vs. whole breast and regional nodal irradiation. In the ALLIANCE A011202 (NCT01901094) trial, women with node-positive status before NACT receive SLNB at the time of surgery. Patients with axillary residual disease are randomized to completion ALND and RNI vs. RNI alone.

\section{The AXSANA Study: Which Axillary Strategy Is Optimal in the $\mathrm{cN}+\rightarrow$ ycNo Setting?}

AXSANA, initiated by EUBREAST (http://axsana.eubreast.com; accessed on 27 March 2021, Figure 1), is a large, prospective, non-interventional cohort study aiming to evaluate the role of axillary treatment in $\mathrm{cN}+$ patients undergoing NACT. With a target accrual of 3000 patients, the study is expected to be able to resolve several open issues. Patients with clinically positive nodal status at time of diagnosis who are scheduled to receive axillary surgery after NACT can be enrolled. Axillary staging procedures and treatment modalities are chosen at the discretion of the treating physicians and according to national and institutional guidelines. Inclusion and exclusion criteria are presented in Table 8. Follow-up is annually during the first five years after surgery. Arm morbidity and quality of life are evaluated at baseline and after 1,3, and 5 years, using four val- 
idated questionnaires (EORTC QLQ-C 30, EORTC QLQ BR 23, Lymph-ICF, and Sense of Coherence). Financial support has been provided by the AGO-B study group, the AWOgyn (German Working Group for Reconstructive Surgery in Oncology-Gynecology), Claudia von Schilling Foundation for Breast Cancer Research, EndoMag, Mammotome, and MeritMedical. AXSANA is further supported by the North-Eastern German Society of Gynecological Oncology (NOGGO) and the German Breast Group (GBG).

Table 8. The AXSANA study: Inclusion and exclusion criteria.

\begin{tabular}{|c|c|}
\hline Inclusion Criteria & Exclusion Criteria \\
\hline $\begin{array}{l}\text { - } \\
\text { - } \quad \text { Prigned informed consent form } \\
\text { (confirmed by core biopsy) } \\
\text { cN+ (confirmed by core biopsy / fine } \\
\text { needle aspiration or presence of highly } \\
\text { suspicious axillary node(s) on imaging) } \\
\text { In case a minimally invasive biopsy of } \\
\text { axillary lymph node(s) has been } \\
\text { performed and yielded a negative or } \\
\text { inconclusive result, patients may be } \\
\text { included if the final classification after } \\
\text { imaging-pathology-correlation is cN+ } \\
\text { cT1-cT4c } \\
\text { - } \\
\text { Scheduled for neoadjuvant systemic } \\
\text { therapy } \\
\text { Female/male patients } \geq 18 \text { years old }\end{array}$ & $\begin{array}{l}\text { Distant metastasis } \\
\text { Recurrent breast cancer } \\
\text { Inflammatory breast cancer } \\
\text { Extramammary breast cancer } \\
\text { Bilateral breast cancer } \\
\text { History of invasive breast cancer, ductal } \\
\text { carcinoma in situ, or any other invasive cancer } \\
\text { Confirmed or suspected supraclavicular lymph } \\
\text { node metastasis } \\
\text { Confirmed or suspected parasternal lymph } \\
\text { node metastasis } \\
\text { Axillary surgery before NACT (e.g., SLNB or } \\
\text { nodal sampling) } \\
\text { Pregnancy } \\
\text { Less than } 4 \text { cycles of NACT administered } \\
\text { Patients not suitable for surgical treatment }\end{array}$ \\
\hline
\end{tabular}

Primary study endpoints:

- 5-year invasive disease-free survival (iDFS)

- 3-year axillary recurrence rate

- Quality of life and arm morbidity

Secondary study endpoints:

- Feasibility of different axillary staging strategies assessed by detection rates for SLN and/or TLN

- Success rate of nodal staging using different axillary staging techniques

- Number of removed lymph nodes and their association to complications, arm morbidity, and quality of life

- Operating time as a surrogate parameter for surgical resources

- Proportion of node-positive patients according to the strategy used (as a surrogate parameter for FNR)

- Factors associated with successful detection of the TLN

- Impact of learning curve on success rates of TAD

- Surgical standards of care in different European countries

- Treatment decisions in case of ypN+ status following NACT (ALND vs. radiation therapy)

- $\quad$ iDFS in patients with ypN+ status who received ALND or radiotherapy or both

- Analysis of factors contributing to a decreased quality of life and subjective symptoms of arm morbidity, i.e., baseline quality of life and sense of coherence, extent of axillary surgery, and other locoregional and systemic therapies received

- Economic resources required for different axillary staging strategies and techniques (material costs, operating time, etc.) 


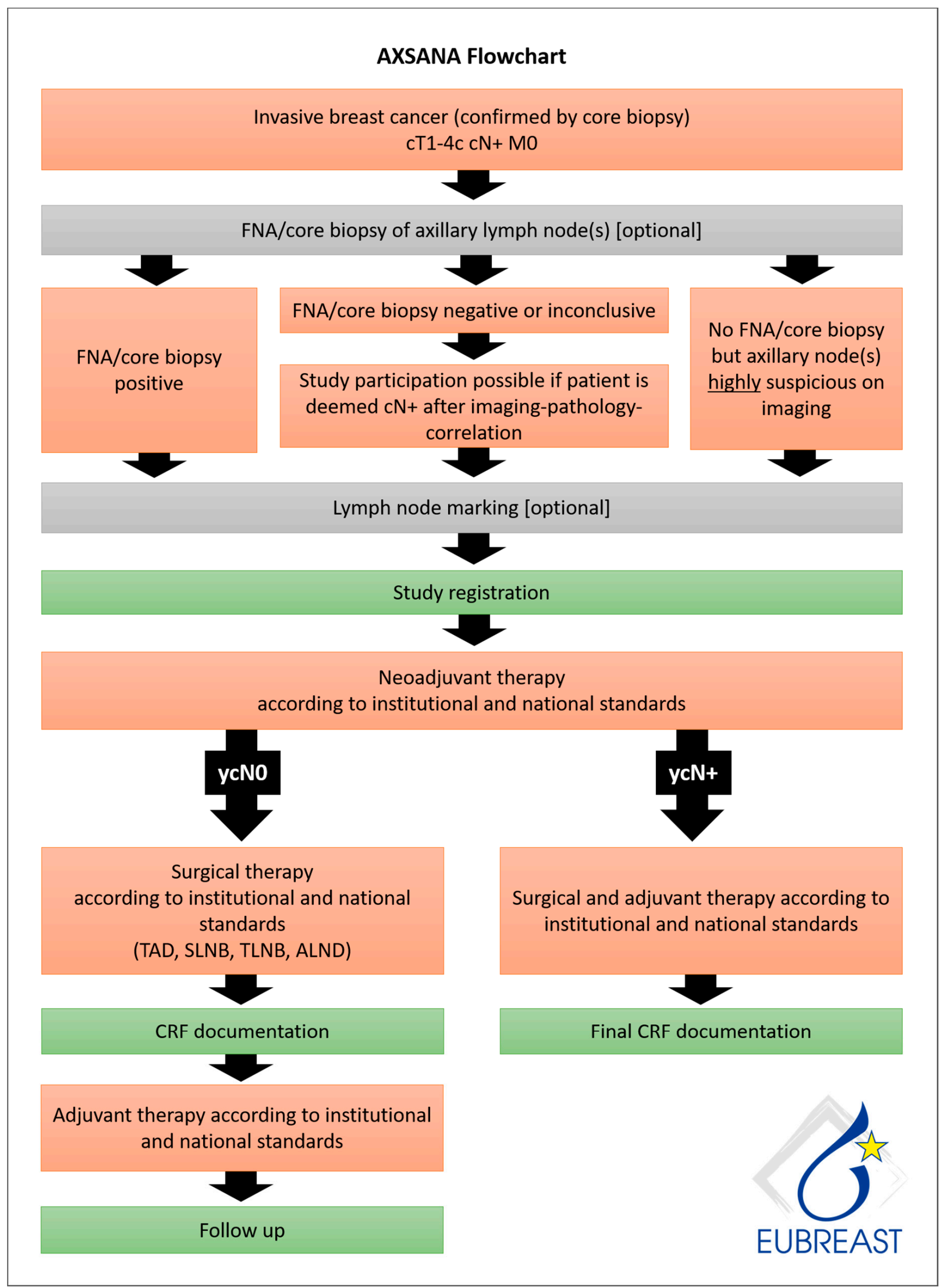

Figure 1. AXSANA flow chart. 
The first AXSANA study site was opened in Germany in June 2020, and recruitment began the same month. Currently, there are 328 patients enrolled. Twenty countries are participating in the study, most of which are in the process of applying for ethical approval. Ten countries have at least one study site open (Figure 2). The study will hopefully address several unanswered issues, such as:

- Which staging technique should be recommended to $\mathrm{cN}+$ patients converting to ycN0?

- Is imaging helpful in identifying patients most likely to achieve pCR in the axilla? If yes, which method should be recommended?

- Should cN1 and cN2/3 patients be offered different surgical strategies for axillary staging?

- Which lymph node marking technique offers highest rates of successful TAD/TLNB?

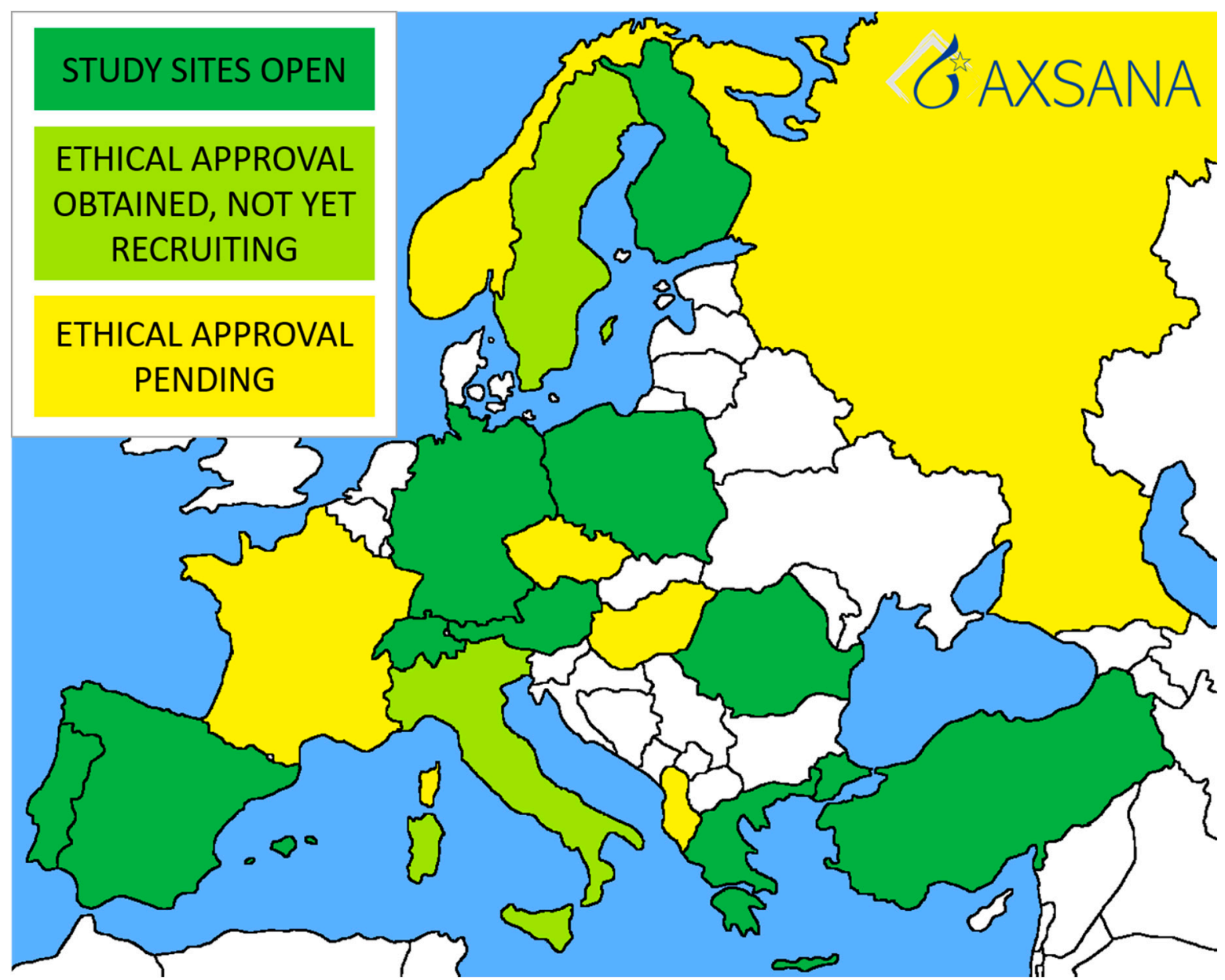

Figure 2. Current status of the AXSANA study.

Due to high complexity and discordant recommendations, a randomized trial comparing different techniques seems hardly feasible and therefore would not clarify currently open issues within a reasonable timeframe. In the AXSANA study, patients are treated at physicians' discretion. To allow comparisons between different cohorts (SLNB, TLNB, TAD, ALND), detailed data regarding clinical and pathological parameters are obtained.

Other currently ongoing studies investigating axillary management in the neoadjuvant setting in $\mathrm{cN}+$ patients are presented in Table 9. 
Table 9. Current trials investigating de-escalation of surgical treatment in $\mathrm{cN}+$ patients undergoing neoadjuvant therapy.

\begin{tabular}{|c|c|c|c|}
\hline Study & Status & Study Design & Primary Endpoint(s) \\
\hline ATNEC NCT04109079 & Not yet recruiting & $\begin{array}{l}\text { Randomized trial } \\
\text { cN+ } \rightarrow \text { ypN0 patients } \\
\text { Surgery: TAD } \\
\text { Marking technique: clip or carbon } \\
\text { suspension } \\
\text { Arms: axillary treatment (ALND } \\
\text { or ART) vs. no axillary treatment }\end{array}$ & $\begin{array}{l}\text { DFS } \\
\text { Patient-reported lymphedema }\end{array}$ \\
\hline AXSANA NCT04373655 & Recruiting since June 2020 & $\begin{array}{l}\text { Non-interventional cohort study } \\
\mathrm{cN}+\text { patients }\end{array}$ & $\begin{array}{l}\text { iDFS } \\
\text { Axillary recurrence rate } \\
\text { Quality of life and arm morbidity }\end{array}$ \\
\hline GANEA 3 NCT03630913 & Recruiting since January 2019 & $\begin{array}{l}\text { Single-arm trial } \\
\text { cN+ patients (confirmed by } \\
\text { biopsy) } \\
\text { Surgery: TAD followed by ALND } \\
\text { Marking technique: clip, marking } \\
\text { of the most suspicious node only }\end{array}$ & $\begin{array}{l}\text { False-negative rate of SLNB, } \\
\text { TLNB, and TAD }\end{array}$ \\
\hline $\begin{array}{l}\text { MAGELLAN } \\
\text { NCT03796559 }\end{array}$ & Recruiting & $\begin{array}{l}\text { Single-arm trial } \\
\text { cN+ patients (confirmed by } \\
\text { biopsy) } \\
\text { Surgery: TAD } \\
\text { Marking technique: clip and } \\
\text { magnetic seed }\end{array}$ & $\begin{array}{l}\text { Retrieval rate of clipped node and } \\
\text { magnetic seed }\end{array}$ \\
\hline Pre-ATNEC NCT03640819 & Completed, results pending & $\begin{array}{l}\text { Single-arm trial } \\
\text { cN+ patients (confirmed by } \\
\text { biopsy) } \\
\text { Surgery: TLNB and-at surgeon's } \\
\text { discretion-SLNB or ALND } \\
\text { Marking technique: carbon } \\
\text { suspension }\end{array}$ & $\begin{array}{l}\text { Identification rate of marked } \\
\text { lymph node(s) }\end{array}$ \\
\hline RISAS NCT02800317 & $\begin{array}{l}\text { Completed, full publication } \\
\text { pending }[43,53]\end{array}$ & $\begin{array}{l}\text { Single-arm trial } \\
\text { cN+ patients (confirmed by } \\
\text { biopsy) } \\
\text { Surgery: TAD followed by ALND } \\
\text { Marking technique: Radioactive } \\
\text { iodine seed }\end{array}$ & $\begin{array}{l}\text { Identification rate, accuracy, and } \\
\text { false negative rate }\end{array}$ \\
\hline TATTOO DRKS00013169 & $\begin{array}{l}\text { Completed, full results pending } \\
{[47,66]}\end{array}$ & $\begin{array}{l}\text { Single-arm trial } \\
\text { cN+ patients (confirmed by } \\
\text { biopsy) } \\
\text { Surgery: TAD or TLNB + ALND } \\
\text { Marking technique: carbon } \\
\text { suspension }\end{array}$ & Detection rate of the TLN \\
\hline $\begin{array}{c}\text { TAXIS [67] } \\
\text { NCT03513614 }\end{array}$ & Recruiting & $\begin{array}{l}\text { Randomized phase III trial } \\
\text { cN+ patients } \\
\text { Surgery: tailored axillary surgery } \\
\text { with or without ALND followed } \\
\text { by radiotherapy }\end{array}$ & DFS \\
\hline NCT03718455 & $\begin{array}{l}\text { Terminated due to limited } \\
\text { operating room availability }\end{array}$ & $\begin{array}{l}\text { Single-arm trial } \\
\mathrm{cN}+\text { patients (confirmed by } \\
\text { biopsy) } \\
\text { Marking technique: Magnetic } \\
\text { seed }\end{array}$ & Detection rate of the TLN \\
\hline NCT03411070 & Recruiting & $\begin{array}{l}\text { Single-arm trial } \\
\text { cN+ patients } \\
\text { Surgery: } \\
\text { Marking technique: radar } \\
\text { reflector-localization clip }\end{array}$ & $\begin{array}{l}\text { Rate of successful removal of the } \\
\text { TLN }\end{array}$ \\
\hline
\end{tabular}

Abbreviations: ALND—axillary lymph node dissection, ART—axillary radiation therapy, DFS—disease-free survival, iDFS—invasive disease-free survival, TAD—-targeted axillary dissection, TLN—target lymph node. 


\section{Conclusions}

In view of continuously improving primary systemic treatments with increasing response rates, there is an urgent need to adapt and de-escalate strategies for axillary surgery, since it is strongly associated with postoperative morbidity. While SLNB has successfully replaced ALND as a staging procedure in primary surgery and after NACT for patients with an initial cN0 status, there is an ongoing debate on appropriate axillary staging for patients who convert from $\mathrm{cN}+$ to $\mathrm{ycN}$.

This review revealed heterogeneous guideline recommendations and practice throughout the international community. This observation is explained by the lack of evidence concerning minimally invasive staging procedures like SLNB or TAD and their association with oncological outcomes, arm morbidity, and quality of life. The review also identified a multitude of unresolved issues regarding indications, surgical staging procedures, and technical aspects of lymph node marking. As a consequence, the European Breast Cancer Research Association of Surgical Trialists (EUBREAST) initiated a prospective cohort study that will allow the assessment of clinically relevant parameters in different axillary staging procedures after NACT, and of many open issues that have been highlighted here. AXSANA is open for all countries provided that patients receive treatment according to current international standards (http:/ / axsana.eubreast.com, accessed on 27 March 2021).

Author Contributions: M.B.-P.: Conceptualization, Data curation, Project administration, Investigation, Writing—original draft, Writing—review \& editing; M.L.G.: Conceptualization, Data curation, Project administration, Investigation, Writing—original draft, Writin—review \& editing; J.d.B.: Conceptualization, Project administration, Investigation, Writing-review \& editing; O.G., E.S. (Elmar Stickeler): Conceptualization, Project administration, Investigation, Writing—review \& editing; S.H.: Investigation, Project administration, Writing—review \& editing; M.T.: Conceptualization, Investigation, Project administration, Writing—review \& editing; I.T.R.: Investigation, Project administration, Writing—review \& editing; R.D.M., E.-A.B., L.N., M.K., G.K.C., M.H., F.P., D.P., Z.M., D.M., G.K., L.D., H.N., P.K., J.-M.C., E.S. (Ellen Schlichting), M.A., C.S., J.-U.B.: Investigation, Project administration, Writing-review \& editing; P.P.: Data curation, Writing—original draft, Writing-review \& editing; T.K.: Conceptualization, Data curation, Investigation, Project administration, Writing-original draft, Writing-review \& editing. All authors have read and agreed to the published version of the manuscript.

Funding: The funding of the AXSANA study has been described in detail in the manuscript.

Institutional Review Board Statement: Not applicable.

Informed Consent Statement: Not applicable.

Data Availability Statement: No new data were created or analyzed in this study. Data sharing is not applicable to this article.

Acknowledgments: We thank Angelika Jursik, Jana Shabbir, Marina Mangold and Jeanette Zeppenfeld for their excellent coordination of the AXSANA study, and Sarah Fröhlich for her invaluable help with study monitoring. We would also like to thank all study site staff members involved in the study.

Conflicts of Interest: The AXSANA study has received financial support from EndoMag, Mammotome. and MeritMedical. The funding sources had no role in the design of the study and will not have any role during analysis and interpretation of the data, or decision to submit results. M.B.P. received honoraria for lectures and participation in advisory boards from: Roche, Novartis, Pfizer, Eli Lilly, Eisai, and AstraZeneca. M.T. received honoraria for participation in advisory boards from: Amgen, AstraZeneca, Biom`Up, Celgene, ClearCut, Clovis, Daiichi Sankyo, Eisai, Exact Sciences, GSK, Lilly, MSD, Norgine, Neodynamics, Novartis, onkowissen.de, Pfizer, pfm medical, Pierre-Fabre, Roche, RTI Surgical, Sysmex, Tesaro; manuscript support from: Amgen, Celgene, Clearcut, pfm medical, Roche; travel reimbursement from: Amgen, Art Tempi, AstraZeneca, Celgene, Clovis, Connect Medica, Daiichi Sankyo, Eisai, Exact Sciences, Hexal, I-Med-Institute, Lilly, MCI, Medtronic, MSD, Norgine, Novartis, Omniamed, Pfizer, pfm Medical, Roche, RTI Surgical, Tesaro; congress support: Amgen, AstraZeneca, Celgene, Daiichi Sanyko, Hexal, Novartis, Pfizer, Roche; honoraria for lectures from: Amgen, Art Tempi, AstraZeneca, Celgene, Clovis, Connect Medica, Daiichi Sankyo, 
Eisai, Exact Sciences, Gedeon Richter, Hexal, I-Med-Institute, Lilly, MCI, Medtronic, MSD, Novartis, onkowissen.de, Omniamed, Pfizer, pfm medical, Roche, RTI Surgical, Sysmex, Vifor; trial funding from: Endomag, Exact Sciences. Other authors declare no conflicts of interest.

\section{Appendix A}

Appendix A.1. Members of the AXSANA Study Group

Achim Rody
Agnieszka Lawnicka
Alexander Emelyanov
Alexander Miller
Anastasia Fleuster
Andrea Hasse
Andrea Papadia
Andrea Stefek
Andreas Rempen
Andreas Schnelzer
Andree Faridi
Angelika Jursik
Anja Graf
Anke Klein-Tebbe
Antje Nixdorf
Antonio Jesus Esgueva Colmenarejo
Arzu Akan
Atakan Sezer
Aysegul Aktas
Barbara Schlesinger
Beatrix Janke
Benno Lex
Carina Paschold
Carolin Nestle-Krämling
Cem Yilmaz
Christine Ankel
Christoph Anthuber
Christoph Großmann
Cihan Uras
Claudia Rauh
Cordula Müller
Cornelia Meisel
Cumhur Arici
Daniela Dieterle
Daniele Bolla
Dirk G. Kieback
Dirk-Michael Watermann
Dorothea Fischer
Eike Simon
Ekkehard von Abel
Elisabeth Thiemann
Elke Faust
Elke Keil
Elvira Schomann
Emmanuel Barranger
Enes Arikan
Eva-Maria Jahn
Felix Hilpert
Florian Ebner
Francesco Meani
Frank Beldermann
Gabriele Feisel-Schwickardi
Gabriele Kaltenecker
Gunay Gurleyik
Hanna Barmettler
Hanna Karlsson
Hans-Christian Kolberg
Hans-Joachim Strittmatter
Hasan Karanlik
Heiko Graf
Helena Ikonomidis Sackey

Lelia Bauer

Manfred Hofmann

Manuela Seixas

Maria Hufnagel

Maria Joao Cardoso

Marina Mangold

Marjut Leidenius

Markus Hahn

Markus Keller

Martin C. Koch

Matthias Frank

Michael Berghorn

Michael Burkhardt

Michael David Mueller

Michael Schrauder

Michael Untch

Michael Weige

Michal Bak

Muneer Mansour

Mustafa Aydogdu

Mustafa Celalettin Ugur

Nana Bündgen

Natalia Krawczyk

Natalija Deuerling

Nicole Rotmensz

Nicoleta Zenovia Antone

Nina Ditsch

Ninette Scharle

Oliver Behrens

Oliver Hoffmann

Oumar Camara

Pavlina Diem

Petra Bolkenius

Prodromos Kanavidis

Renu Buss-Steidle

Ricardo Felberbaum

Richard Berger

Roberto Rodriguez

Rodoniki Iosifidou

Roland Csorba

Sabine Lemster

Sabine Riemer

Sandra Rauen

Sarah Fröhlich

Sebastian Wojcinski

Semra Gunay

Sibel Ozkan Gurdal

Sibylle Perez

Silke Mattes

Sonja Cárdenas-Ovalle

Stefan Hupfer

Stefan Paepke

Stefan Renner

Stefanie Buchen

Stefanie Strobel

Steffen Liebers

Stephan Hasmüller

Stephan Seitz

Sudip Kundu

Susanne Albrecht

Susanne Bucher 


$\begin{array}{ll}\text { Henning Eichler } & \text { Susanne Kraudelt } \\ \text { Inga Bekes } & \text { Susanne Steer } \\ \text { Ingo Bauerfeind } & \text { Susen Schirrmeister } \\ \text { Ingo Thalmann } & \text { Sven-Thomas Graßhoff } \\ \text { Ingrid Buck } & \text { Tanja Fehm } \\ \text { Ioannis Natsiopoulos } & \text { Tanja Wanik } \\ \text { Isabelle Himsl } & \text { Telja Pursche } \\ \text { Isabelle Utz-Billing } & \text { Thomas Hawighorst } \\ \text { Jana Shabbir } & \text { Thomas Müller } \\ \text { Jeanette Zeppenfeld } & \text { Thomas Papathemilis } \\ \text { Jenci Palatty } & \text { Tuomo Meretoja } \\ \text { Jens Paul Seldte } & \text { Umit Ugurlu } \\ \text { Jens Schnabel } & \text { Ursula Makowiec } \\ \text { Joachim Rom } & \text { Ursula Scholz } \\ \text { Jose Ignacio Sanchez Mendez } & \text { Ute-Susann Albert } \\ \text { Jürgen Schuster } & \text { Vasileios Sevas } \\ \text { Jutta Lefarth } & \text { Veli Vural } \\ \text { Karen Wimmer } & \text { Visnja Fink } \\ \text { Kathrin Engelken } & \text { Vlad Alexandru Gata } \\ \text { Katja Vassilev } & \text { Volker Hanf } \\ \text { Katrin Sawitzki } & \text { Wencke Ruhwedel } \\ \text { Kerstin Hilmer } & \text { Wolfram Seifert } \\ \text { Kerstin Ramaker } & \text { Yvonne Wengström } \\ \text { Kilin Pame }\end{array}$

Kilian Pankert

Appendix A.2. Active Study Sites

\section{Austria}

LKH Hochsteiermark, Standort Leoben

\section{Germany}

Klinikum Esslingen

UFK Rostock

Leopoldina-Krankenhaus

Städtisches Klinikum Karlsruhe Frauenklinik

Klinikum Aschaffenburg-Alzenau

Klinikum Stuttgart-Frauenklinik

MVZ Klinik Dr. Hancken GmbH

Marienhospital Bottrop gGmbH

Kreiskrankenhaus Bergstraße $\mathrm{GmbH}$

Klinikum Memmingen

Brustzentrum Pinneberg

Ortenau Klinikum Offenburg-Kehl

Klinikum Fichtelgebierge

Klinikum Ansbach

Brustzentrum, Sana Klinikum Berlin Lichtenberg

RWTH Uniklinik Aachen

Medius Klinik Nürtingen

Klinikum St. Marien Amberg

Klinikum Landkreis Tuttlingen

Brustzentrum Diakonieklinikum Stuttgart

Brustzentrum Südbaden

WKK Westküstenkliniken Heide

Marienhospital Stuttgart

AKH Celle

Vidia Christliche Kliniken Karlsruhe Diakonissenkrankenhaus

Agaplesion Krankenhaus Frankfurt

Klinikum Gütersloh

Siloah St Trudpert Klinikum

Brustzentrum Donau-Riß, Alb-Donau-Klinikum Ehingen

Franziskus Hospital Bielefeld

Brustzentrum Gelnhausen

München Klinik Harlaching Frauenklinik

Kreiskrankenhaus Torgau

Imland gGmbH Rendsburg

Friedrich-Ebert-Krankenhaus

Brustzentrum Sömmerda 


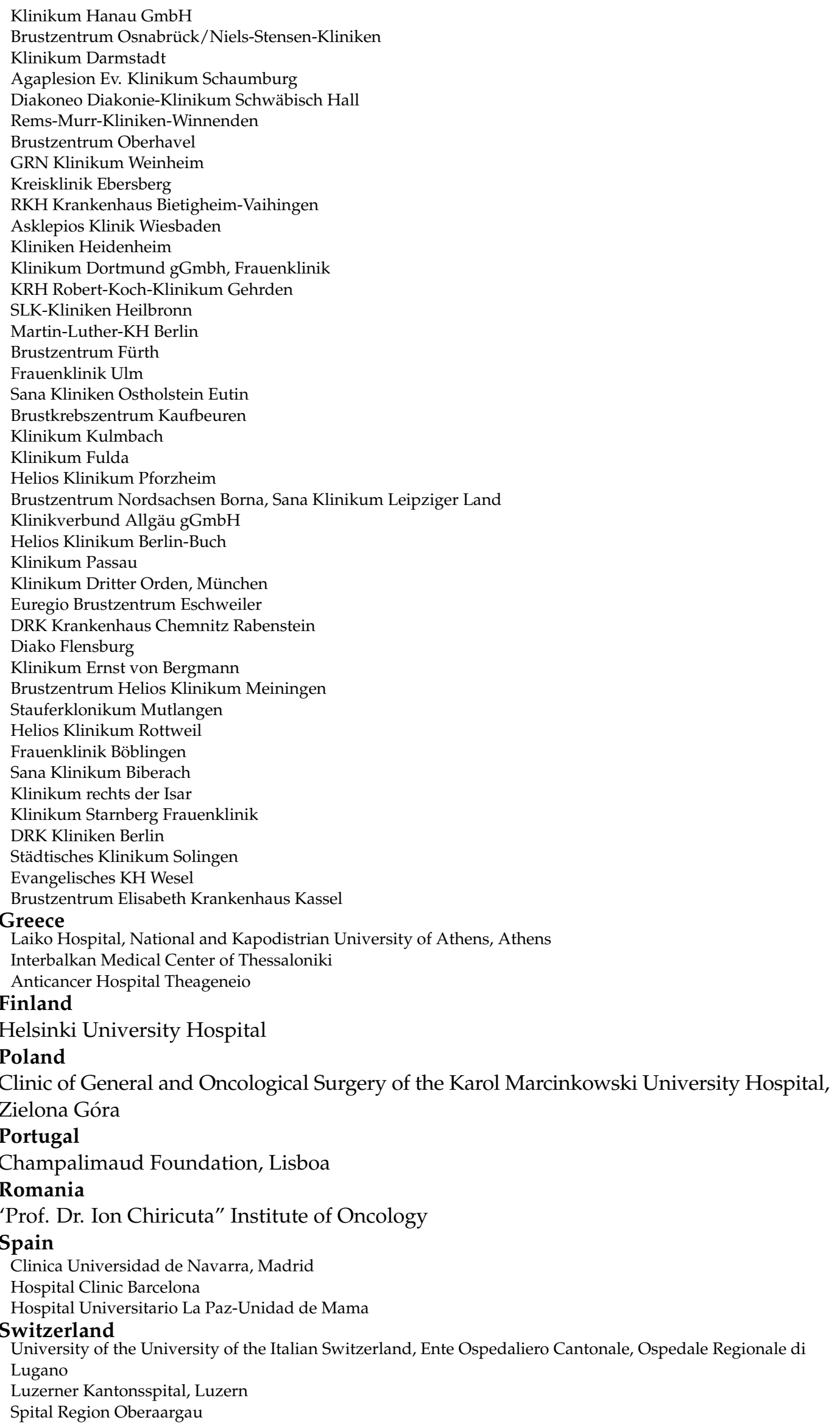




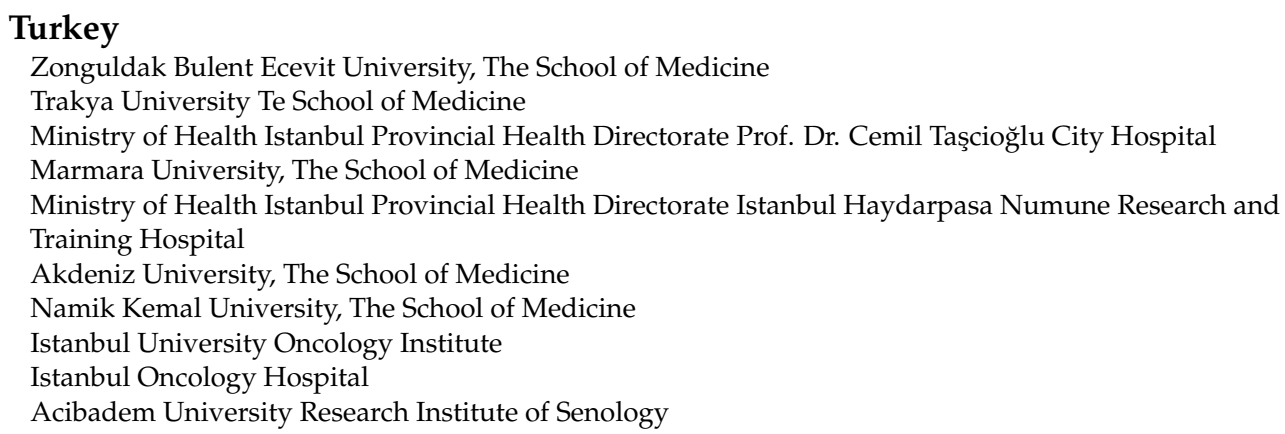

\section{References}

1. Classe, J.M.; Loaec, C.; Gimbergues, P.; Alran, S.; de Lara, C.T.; Dupre, P.F.; Rouzier, R.; Faure, C.; Paillocher, N.; Chauvet, M.P.; et al. Sentinel lymph node biopsy without axillary lymphadenectomy after neoadjuvant chemotherapy is accurate and safe for selected patients: The GANEA 2 study. Breast Cancer Res. Treat. 2019, 173, 343-352. [CrossRef]

2. Hunt, K.K.; Yi, M.; Mittendorf, E.A.; Guerrero, C.; Babiera, G.V.; Bedrosian, I.; Hwang, R.F.; Kuerer, H.M.; Ross, M.I.; MericBernstam, F. Sentinel lymph node surgery after neoadjuvant chemotherapy is accurate and reduces the need for axillary dissection in breast cancer patients. Ann. Surg. 2009, 250, 558-566. [CrossRef] [PubMed]

3. Kahler-Ribeiro-Fontana, S.; Pagan, E.; Magnoni, F.; Vicini, E.; Morigi, C.; Corso, G.; Intra, M.; Canegallo, F.; Ratini, S.; Leonardi, M.C.; et al. Long-term standard sentinel node biopsy after neoadjuvant treatment in breast cancer: A single institution ten-year follow-up. Eur. J. Surg. Oncol. 2021, 47, 804-812. [CrossRef] [PubMed]

4. Kuehn, T.; Bauerfeind, I.; Fehm, T.; Fleige, B.; Hausschild, M.; Helms, G.; Lebeau, A.; Liedtke, C.; von Minckwitz, G.; Nekljudova, V.; et al. Sentinel-lymph-node biopsy in patients with breast cancer before and after neoadjuvant chemotherapy (SENTINA): A prospective, multicentre cohort study. Lancet Oncol. 2013, 14, 609-618. [CrossRef]

5. Boughey, J.C.; Suman, V.J.; Mittendorf, E.A.; Ahrendt, G.M.; Wilke, L.G.; Taback, B.; Leitch, A.M.; Kuerer, H.M.; Bowling, M.; Flippo-Morton, T.S.; et al. Sentinel lymph node surgery after neoadjuvant chemotherapy in patients with node-positive breast cancer: The ACOSOG Z1071 (Alliance) clinical trial. JAMA 2013, 310, 1455-1461. [CrossRef]

6. Chehade, H.E.H.; Headon, H.; El Tokhy, O.; Heeney, J.; Kasem, A.; Mokbel, K. Is sentinel lymph node biopsy a viable alternative to complete axillary dissection following neoadjuvant chemotherapy in women with node-positive breast cancer at diagnosis? An updated meta-analysis involving 3,398 patients. Am. J. Surg. 2016, 212, 969-981. [CrossRef]

7. Boughey, J.C.; Ballman, K.V.; Le-Petross, H.T.; McCall, L.M.; Mittendorf, E.A.; Ahrendt, G.M.; Wilke, L.G.; Taback, B.; Feliberti, E.C.; Hunt, K.K. Identification and Resection of Clipped Node Decreases the False-negative Rate of Sentinel Lymph Node Surgery in Patients Presenting With Node-positive Breast Cancer (T0-T4, N1-N2) Who Receive Neoadjuvant Chemotherapy: Results From ACOSOG Z1071 (Alliance). Ann. Surg. 2016, 263, 802-807. [CrossRef] [PubMed]

8. Caudle, A.S.; Yang, W.T.; Krishnamurthy, S.; Mittendorf, E.A.; Black, D.M.; Gilcrease, M.Z.; Bedrosian, I.; Hobbs, B.P.; DeSnyder, S.M.; Hwang, R.F.; et al. Improved Axillary Evaluation Following Neoadjuvant Therapy for Patients With Node-Positive Breast Cancer Using Selective Evaluation of Clipped Nodes: Implementation of Targeted Axillary Dissection. J. Clin. Oncol. 2016, 34, 1072-1078. [CrossRef]

9. NCCN Clinical Practice Guidelines in Oncology, Breast Cancer, Version 1.2021-15 January 2021. NCCN.org. 2021. Available online: https://www.nccn.org/professionals/physician_gls/default.aspx\#breast (accessed on 27 March 2021).

10. Cardoso, F.; Kyriakides, S.; Ohno, S.; Penault-Llorca, F.; Poortmans, P.; Rubio, I.T.; Zackrisson, S.; Senkus, E.; Committee, E.G. Early breast cancer: ESMO Clinical Practice Guidelines for diagnosis, treatment and follow-up. Ann. Oncol. 2019, $30,1674$. [CrossRef]

11. Recommendations of the AGO Breast Committee: Diagnosis and Treatment of Patients with early and advanced Breast Cancer. Available online: www.ago-online.de (accessed on 27 March 2021).

12. Banys-Paluchowski, M.; Gruber, I.V.; Hartkopf, A.; Paluchowski, P.; Krawczyk, N.; Marx, M.; Brucker, S.; Hahn, M. Axillary ultrasound for prediction of response to neoadjuvant therapy in the context of surgical strategies to axillary dissection in primary breast cancer: A systematic review of the current literature. Arch. Gynecol. Obstet. 2020, 301, 341-353. [CrossRef]

13. Consensus Guideline on the Management of the Axilla in Patients with Invasive/In-Situ Breast Cancer. The American Society of Breast Surgeons. 2019. Available online: https:/ / www.breastsurgeons.org/docs/statements/Consensus-Guideline-on-theManagement-of-the-Axilla.pdf?v2 (accessed on 27 March 2021).

14. Finnish Breast Cancer Group. Rintasyöpäryhmän Valtakunnallinen Diagnostiikka-Ja Hoitosuositus. Available online: https:/ /1587667.167.directo.fi/@Bin/c554c241df494d864925e07ad6aa705e/1614023914/application/pdf/186425/SRSR_ Suositus_2019\%20Joulukuu.pdf (accessed on 1 December 2019).

15. Leitlinienprogramm Onkologie (Deutsche Krebsgesellschaft, Deutsche Krebshilfe, AWMF): S3-Leitlinie Früherkennung, Diagnose, Therapie und Nachsorge des Mammakarzinoms, Version 4.3, AWMF Registernummer: 032-045OL. Available online: http: / / www.leitlinienprogramm-onkologie.de/leitlinien/mammakarzinom/ (accessed on 10 June 2020).

16. Lazar, G.; Kelemen, P.; Kosa, C.; Maraz, R.; Paszt, A.; Pavlovics, G.; Savolt, A.; Simonka, Z.; Toth, D.; Matrai, Z. Modern surgical treatment of breast cancer. 4th Breast Cancer Consensus Conference. Magy Onkol. 2020, 64, 329-346. [PubMed] 
17. Indian Council of Medical Research Consensus Document for Management of Breast Cancer; Department of Health Research MoHFW: New Delhi, India, 2016.

18. Recommendations of the Polish Society of Surgical Oncology (Surgical Treatment in Breast Neoplasms: Second Consensus). 2019. Available online: https://journals.viamedica.pl/oncology_in_clinical_practice/article/view/OCP.2017.0015/43197 (accessed on 27 March 2021).

19. Ghid de Management al Cancerului Mamar. Available online: http://old.ms.ro/index.php?pag=181\&pg=5 (accessed on 1 December 2009).

20. Peltecu, G.; Median, D.; Vlad, Ș.; Tuinea, L.; Iancu, G.; Gică, N.; Nedelea, F.; Cigăran, R.; Chirculescu, R.; Lesaru, M.; et al. Cancerul Mamar. Societatea de Obstetrica si Ginecologie. Available online: https://sogr.ro/wp-content/uploads/2019/06/30. Cancerul-mamar.pdf (accessed on 26 February 2021).

21. Bröstcancer-Nationellt Vårdprogram-SweBCG, 2020-02-11 Version: 3.0. Available online: http://www.swebcg.se/wp-content/ uploads/2016/10/nationellt-vardprogram-brostcancer_200211.pdf (accessed on 1 December 2020).

22. Neoadjuverende Kemoterapi ved Brystkræft mhp. Down-Sizing og Down-Staging. In Danish Breast Cancer Group Guidelines, Danish Breast Cancer Group: Aarhus, Denmark, 2016.

23. Associazione Italiana di Oncologia Medica (AIOM). Breast Neoplasms Guidelines, 2018 ed.; Associazione Italiana di Oncologia Medica (AIOM): Milan, Italy, 2019.

24. IX Consenso Nacional de Cancro de Mama; Sociedade Portuguesa de Senologia: Coimbra, Portugal, 2017.

25. Clinical Guidelines Mammary Cancer; ПрофессиональныеАссоциации: Ассоциацияонкологов России Российскоеобщество клиническойонкологии: Moscow, Russia, 2018.

26. De La Peña, F.A.; Andrés, R.; Garcia-Sáenz, J.A.; Manso, L.; Margelí, M.; Dalmau, E.; Pernas, S.; Prat, A.; Servitja, S.; Ciruelos, E. SEOM clinical guidelines in early stage breast cancer (2018). Clin. Transl. Oncol. 2019, 21, 18-30. [CrossRef]

27. Boileau, J.F.; Poirier, B.; Basik, M.; Holloway, C.M.; Gaboury, L.; Sideris, L.; Meterissian, S.; Arnaout, A.; Brackstone, M.; McCready, D.R.; et al. Sentinel node biopsy after neoadjuvant chemotherapy in biopsy-proven node-positive breast cancer: The SN FNAC study. J. Clin. Oncol. 2015, 33, 258-264. [CrossRef]

28. Reinisch, M.; Heil, J.; Rüland, A.; Seiberling, C.; Harrach, H.; Schindowski, D.; Lubitz, J.; Ankel, C.; Grasshoff, S.T.; Deuschle, P.; et al. Prospective, multicenter registry trial to evaluate the clinical feasibility of targeted axillary dissection (TAD) in patients (pts) with breast cancer (BC) and core biopsy proven axillary involvement (cN+). Ann. Oncol. 2019, 30, v56. [CrossRef]

29. Kuemmel, S.; Heil, J.; Rueland, A.; Seiberling, C.; Harrach, H.; Schindowski, D.; Lubitz, J.; Hellerhoff, K.; Ankel, C.; Grasshoff, S.T.; et al. A Prospective, Multicenter Registry Study to Evaluate the Clinical Feasibility of Targeted Axillary Dissection (TAD) in Node-Positive Breast Cancer Patients. Ann. Surg. 2020, 4. [CrossRef] [PubMed]

30. Plecha, D.; Bai, S.; Patterson, H.; Thompson, C.; Shenk, R. Improving the Accuracy of Axillary Lymph Node Surgery in Breast Cancer with Ultrasound-Guided Wire Localization of Biopsy Proven Metastatic Lymph Nodes. Ann. Surg. Oncol. 2015, 22, 4241-4246. [CrossRef]

31. Laws, A.; Dillon, K.; Kelly, B.N.; Kantor, O.; Hughes, K.S.; Gadd, M.A.; Smith, B.L.; Lamb, L.R.; Specht, M. Node-Positive Patients Treated with Neoadjuvant Chemotherapy Can Be Spared Axillary Lymph Node Dissection with Wireless Non-Radioactive Localizers. Ann. Surg. Oncol. 2020, 27, 4819-4827. [CrossRef]

32. Nguyen, T.T.; Hieken, T.J.; Glazebrook, K.N.; Boughey, J.C. Localizing the Clipped Node in Patients with Node-Positive Breast Cancer Treated with Neoadjuvant Chemotherapy: Early Learning Experience and Challenges. Ann. Surg. Oncol. 2017, 24, 3011-3016. [CrossRef] [PubMed]

33. Simons, J.M.; Scoggins, M.E.; Kuerer, H.M.; Krishnamurthy, S.; Yang, W.T.; Sahin, A.A.; Shen, Y.; Lin, H.; Bedrosian, I.; Mittendorf, E.A.; et al. Prospective Registry Trial Assessing the Use of Magnetic Seeds to Locate Clipped Nodes After Neoadjuvant Chemotherapy for Breast Cancer Patients. Ann. Surg. Oncol. 2021, 8, 1-7. [CrossRef]

34. Siso, C.; de Torres, J.; Esgueva-Colmenarejo, A.; Espinosa-Bravo, M.; Rus, N.; Cordoba, O.; Rodriguez, R.; Peg, V.; Rubio, I.T. Intraoperative Ultrasound-Guided Excision of Axillary Clip in Patients with Node-Positive Breast Cancer Treated with Neoadjuvant Therapy (ILINA Trial): A New Tool to Guide the Excision of the Clipped Node After Neoadjuvant Treatment. Ann. Surg. Oncol. 2018, 25, 784-791. [CrossRef]

35. Sun, J.; Henry, D.A.; Carr, M.J.; Yazdankhahkenary, A.; Laronga, C.; Lee, M.C.; Hoover, S.J.; Sun, W.; Czerniecki, B.J.; Khakpour, N.; et al. Feasibility of Axillary Lymph Node Localization and Excision Using Radar Reflector Localization. Clin. Breast Cancer 2020. In Press. [CrossRef]

36. Hartmann, S.; Reimer, T.; Gerber, B.; Stubert, J.; Stengel, B.; Stachs, A. Wire localization of clip-marked axillary lymph nodes in breast cancer patients treated with primary systemic therapy. Eur. J. Surg. Oncol. 2018, 44, 1307-1311. [CrossRef]

37. Diego, E.J.; McAuliffe, P.F.; Soran, A.; McGuire, K.P.; Johnson, R.R.; Bonaventura, M.; Ahrendt, G.M. Axillary Staging After Neoadjuvant Chemotherapy for Breast Cancer: A Pilot Study Combining Sentinel Lymph Node Biopsy with Radioactive Seed Localization of Pre-treatment Positive Axillary Lymph Nodes. Ann. Surg. Oncol. 2016, 23, 1549-1553. [CrossRef]

38. Martínez, A.M.; Roselló, I.V.; Gómez, A.S.; Catanese, A.; Molina, M.P.; Suarez, M.S.; Miguel, I.P.; Aulina, L.B.; Gozálvez, C.R.; Ibáñez, J.F.J.; et al. Advantages of preoperative localization and surgical resection of metastatic axillary lymph nodes using magnetic seeds after neoadjuvant chemotherapy in breast cancer. Surg. Oncol. 2021, 36, 28-33. [CrossRef] 
39. Kim, W.H.; Kim, H.J.; Kim, S.H.; Jung, J.H.; Park, H.Y.; Lee, J.; Kim, W.W.; Park, J.Y.; Chae, Y.S.; Lee, S.J. Ultrasound-guided dual-localization for axillary nodes before and after neoadjuvant chemotherapy with clip and activated charcoal in breast cancer patients: A feasibility study. BMC Cancer 2019, 19, 859. [CrossRef] [PubMed]

40. Balasubramanian, R.; Morgan, C.; Shaari, E.; Kovacs, T.; Pinder, S.E.; Hamed, H.; Sever, A.R.; Kothari, A. Wire guided localisation for targeted axillary node dissection is accurate in axillary staging in node positive breast cancer following neoadjuvant chemotherapy. Eur. J. Surg. Oncol. 2020, 46, 1028-1033. [CrossRef] [PubMed]

41. Lim, G.H.; Teo, S.Y.; Gudi, M.; Ng, R.P.; Pang, J.; Tan, Y.S.; Lee, Y.S.; Allen, J.C., Jr.; Leong, L.C.H. Initial results of a novel technique of clipped node localization in breast cancer patients postneoadjuvant chemotherapy: Skin Mark clipped Axillary nodes Removal Technique (SMART trial). Cancer Med. 2020, 9, 1978-1985. [CrossRef] [PubMed]

42. Lim, G.H.; Gudi, M.; Teo, S.Y.; Ng, R.P.; Yan, Z.; Lee, Y.S.; Allen, J.C., Jr.; Leong, L.C.H. Would Removal of All Ultrasound Abnormal Metastatic Lymph Nodes Without Sentinel Lymph Node Biopsy Be Accurate in Patients with Breast Cancer with Neoadjuvant Chemotherapy? Oncologist 2020, 25, e1621-e1627. [CrossRef]

43. Simons, J.; Nijnatten, T.J.V.; Koppert, L.B.; van der Pol, C.C.; Diest, P.J.V.; Jager, A.; Klaveren, D.V.; Kam, B.L.; Lobbes, M.B.; de Boer, M.; et al. Radioactive Iodine Seed placement in the Axilla with Sentinel lymph node biopsy after neoadjuvant chemotherapy in breast cancer: Results of the prospective multicenter RISAS trial. Gen. Sess. Abstr. 2021, 81, GS1-10.

44. Donker, M.; Straver, M.E.; Wesseling, J.; Loo, C.E.; Schot, M.; Drukker, C.A.; van Tinteren, H.; Sonke, G.S.; Rutgers, E.J.; Peeters, M.J.V. Marking axillary lymph nodes with radioactive iodine seeds for axillary staging after neoadjuvant systemic treatment in breast cancer patients: The MARI procedure. Ann. Surg. 2015, 261, 378-382. [CrossRef]

45. Thill, M.; Khandan, F.; Schnitzbauer, T. Magseed ${ }^{\circledR}$-basierte Langzeitmarkierung von Target Lymphknoten bei Patientinnen mit einem Mammakarzinom im Frühstadium unter neoadjuvanter Therapie—Erste Erfahrungen und Perspektiven. GebFra 2020, 80. [CrossRef]

46. Malter, W.; Eichler, C.; Hanstein, B.; Mallmann, P.; Holtschmidt, J. First Reported Use of Radiofrequency Identification (RFID) Technique for Targeted Excision of Suspicious Axillary Lymph Nodes in Early Stage Breast Cancer-Evaluation of Feasibility and Review of Current Recommendations. Vivo 2020, 34, 1207-1213. [CrossRef] [PubMed]

47. Hartmann, S.; Stachs, A.; Kühn, T.; Winckelmann, A.; De Boniface, J.; Gerber, B.; Reimer, T. Target Lymph Node Biopsy (TLNB) nach Kohlenstoffmarkierung bei Mammakarzinom-Patientinnen im Rahmen der primären Systemtherapie-Ergebnisse der TATTOO-Studie (DGGG-Kongress). GebFra 2020, 80, 61. [CrossRef]

48. Natsiopoulos, I.; Intzes, S.; Liappis, T.; Zarampoukas, K.; Zarampoukas, T.; Zacharopoulou, V.; Papazisis, K. Axillary Lymph Node Tattooing and Targeted Axillary Dissection in Breast Cancer Patients Who Presented as cN+ Before Neoadjuvant Chemotherapy and Became cN0 After Treatment. Clin. Breast Cancer 2019, 19, 208-215. [CrossRef] [PubMed]

49. Allweis, T.M.; Menes, T.; Rotbart, N.; Rapson, Y.; Cernik, H.; Bokov, I.; Diment, J.; Magen, A.; Golan, O.; Levi-Bendet, N.; et al. Ultrasound guided tattooing of axillary lymph nodes in breast cancer patients prior to neoadjuvant therapy, and identification of tattooed nodes at the time of surgery. Eur. J. Surg. Oncol. 2020, 46, 1041-1045. [CrossRef]

50. Khallaf, E.; Wessam, R.; Abdoon, M. Targeted axillary dissection of carbon-tattooed metastatic lymph nodes in combination with post-neo-adjuvant sentinel lymph node biopsy using $1 \%$ methylene blue in breast cancer patients. Breast J. 2020, 26, 1061-1063. [CrossRef] [PubMed]

51. Gatek, J.; Petru, V.; Kosac, P.; Ratajsky, M.; Duben, J.; Dudesek, B.; Jancik, P.; Zabojnikova, M.; Katrusak, J.; Opelova, P.; et al. Targeted axillary dissection with preoperative tattooing of biopsied positive axillary lymph nodes in breast cancer. Neoplasma 2020, 67, 1329-1334. [CrossRef]

52. Choy, N.; Lipson, J.; Porter, C.; Ozawa, M.; Kieryn, A.; Pal, S.; Kao, J.; Trinh, L.; Wheeler, A.; Ikeda, D.; et al. Initial results with preoperative tattooing of biopsied axillary lymph nodes and correlation to sentinel lymph nodes in breast cancer patients. Ann. Surg. Oncol. 2015, 22, 377-382. [CrossRef]

53. Van Nijnatten, T.J.A.; Simons, J.M.; Smidt, M.L.; van der Pol, C.C.; van Diest, P.J.; Jager, A.; van Klaveren, D.; Kam, B.L.R.; Lobbes, M.B.I.; de Boer, M.; et al. A Novel Less-invasive Approach for Axillary Staging after Neoadjuvant Chemotherapy in Patients with Axillary Node-positive Breast Cancer by Combining Radioactive Iodine Seed Localization in the Axilla with the Sentinel Node Procedure (RISAS): A Dutch Prospective Multicenter Validation Study. Clin. Breast Cancer 2017, 17, 399-402. [CrossRef] [PubMed]

54. Gera, R.; Tayeh, S.; Al-Reefy, S.; Mokbel, K. Evolving Role of Magseed in Wireless Localization of Breast Lesions: Systematic Review and Pooled Analysis of 1,559 Procedures. Anticancer Res. 2020, 40, 1809-1815. [CrossRef]

55. Kasem, I.; Mokbel, K. Savi Scout(R) Radar Localisation of Non-palpable Breast Lesions: Systematic Review and Pooled Analysis of 842 Cases. Anticancer Res. 2020, 40, 3633-3643. [CrossRef]

56. Lowes, S.; Bell, A.; Milligan, R.; Amonkar, S.; Leaver, A. Use of Hologic LOCalizer radiofrequency identification (RFID) tags to localise impalpable breast lesions and axillary nodes: Experience of the first 150 cases in a UK breast unit. Clin. Radiol. 2020, 75, 942-949. [CrossRef]

57. McGugin, C.; Spivey, T.; Coopey, S.; Smith, B.; Kelly, B.; Gadd, M.; Hughes, K.; Dontchos, B.; Specht, M. Radiofrequency identification tag localization is comparable to wire localization for non-palpable breast lesions. Breast Cancer Res. Treat. 2019, 177, 735-739. [CrossRef] [PubMed]

58. Glaeser, A.; Sinn, H.P.; Garcia-Etienne, C.; Riedel, F.; Hug, S.; Schaefgen, B.; Golatta, M.; Hennigs, A.; Feisst, M.; Sohn, C.; et al. Heterogeneous Responses of Axillary Lymph Node Metastases to Neoadjuvant Chemotherapy are Common and Depend on Breast Cancer Subtype. Ann. Surg. Oncol. 2019, 26, 4381-4389. [CrossRef] [PubMed] 
59. United State Nuclear Regulatory Commission. Low Activity Radioactive Seeds Used for Localization of Non-Palpable Lesions and Lymph Nodes, Licensing Guidance, Revision 1. Available online: https:/ / www.nrc.gov/docs/ML1619/ML16197A568.pdf (accessed on 1 December 2016).

60. Kirkilesis, G.; Constantinidou, A.; Kontos, M. False negativity of targeted axillary dissection in breast cancer. Breast Care 2021. In Press. [CrossRef]

61. Kantor, O.; Sipsy, L.M.; Yao, K.; James, T.A. A Predictive Model for Axillary Node Pathologic Complete Response after Neoadjuvant Chemotherapy for Breast Cancer. Ann. Surg. Oncol. 2018, 25, 1304-1311. [CrossRef] [PubMed]

62. Tadros, A.B.; Yang, W.T.; Krishnamurthy, S.; Rauch, G.M.; Smith, B.D.; Valero, V.; Black, D.M.; Lucci, A., Jr.; Caudle, A.S.; DeSnyder, S.M.; et al. Identification of Patients With Documented Pathologic Complete Response in the Breast After Neoadjuvant Chemotherapy for Omission of Axillary Surgery. JAMA Surg. 2017, 152, 665-670. [CrossRef]

63. Barron, A.U.; Hoskin, T.L.; Day, C.N.; Hwang, E.S.; Kuerer, H.M.; Boughey, J.C. Association of Low Nodal Positivity Rate Among Patients With ERBB2-Positive or Triple-Negative Breast Cancer and Breast Pathologic Complete Response to Neoadjuvant Chemotherapy. JAMA Surg. 2018, 153, 1120-1126. [CrossRef]

64. Esgueva, A.; Siso, C.; Espinosa-Bravo, M.; Sobrido, C.; Miranda, I.; Salazar, J.P.; Rubio, I.T. Leveraging the increased rates of pathologic complete response after neoadjuvant treatment in breast cancer to de-escalate surgical treatments. J. Surg. Oncol. 2021, 123, 71-79. [CrossRef]

65. Koolen, B.B.; Donker, M.; Straver, M.E.; van der Noordaa, M.E.M.; Rutgers, E.J.T.; Olmos, R.A.V.; Peeters, M.V. Combined PET-CT and axillary lymph node marking with radioactive iodine seeds (MARI procedure) for tailored axillary treatment in node-positive breast cancer after neoadjuvant therapy. Br. J. Surg. 2017, 104, 1188-1196. [CrossRef] [PubMed]

66. Hartmann, S.; Stachs, A.; Kühn, T.; Winckelmann, A.; de Boniface, J.; Gerber, B.; Reimer, T. Abstract OT3-01-01: Feasibility of carbon tattooing for targeted lymph node biopsy in breast cancer patients treated by primary systemic therapy (TATTOO trial). Cancer Res. 2019, 80, OT3-01. [CrossRef]

67. Henke, G.; Knauer, M.; Ribi, K.; Hayoz, S.; Gerard, M.A.; Ruhstaller, T.; Zwahlen, D.R.; Muenst, S.; Ackerknecht, M.; Hawle, H.; et al. Tailored axillary surgery with or without axillary lymph node dissection followed by radiotherapy in patients with clinically node-positive breast cancer (TAXIS): Study protocol for a multicenter, randomized phase-III trial. Trials 2018, 19, 667. [CrossRef] [PubMed] 